\title{
Recent climatic and anthropogenic imprints on lacustrine systems in the Pyrenean Mountains inferred from minerogenic and organic clastic supply (Vicdessos valley, Pyrenees, France)
}

$0(0) 1-14$

(c) The Author(s) 2013

Reprints and permissions: sagepub.co.uk/journalsPermissions.nav DOI: $10.1177 / 09596836 \mid 3505340$ hol.sagepub.com

(S)AGE

\author{
Anaëlle Simonneau, ${ }^{1,2}$ Emmanuel Chapron, ' Thierry Courp, ${ }^{3}$ \\ Kazuyo Tachikawa, ${ }^{4}$ Gaël Le Roux, ${ }^{5,6}$ Sandrine Baron, ${ }^{7}$ Didier \\ Galop, ${ }^{2}$ Marta Garcia, ${ }^{4}$ Christian Di Giovanni, ${ }^{1}$ Mikael Motellica- \\ Heino, ${ }^{1}$ Florence Mazier, ${ }^{2}$ Anthony Foucher, ${ }^{8}$ Thomas Houet, ${ }^{2}$ Marc \\ Desmet $^{8}$ and Edouard Bard ${ }^{4}$
}

\begin{abstract}
High-resolution seismic profiling has been combined with geochemical analyses of both watershed samples and five lacustrine cores retrieved from two natural lacustrine basins of glacial origin: Lake Majeur and Lake Sigriou (1630 m a.s.l. and 1995 m a.s.l., respectively, Eastern French Pyrenees). Identifying specific minerogenic and organic markers of autochthonous and allochthonous supply, data allow documenting past climatic and anthropogenic pressures. Over the past century, the lacustrine sediment of Lake Majeur has been essentially composed of algae, drastically contrasting with the natural sedimentary infill of the basin, mainly resulting from soil erosion from the mid-late Holocene. Since AD 1907, the Lake Majeur has been used for hydroelectricity production. Human-induced lake-level regulations, affecting up to $37 \%$ of the lacustrine surface, have increased by fourfold the accumulation rate of the lake and favoured water enrichment. Rubidium abundance within the lacustrine sediments of the two lakes reflects the mid-late Holocene palaeohydrology. After dam construction in AD 1907, greater quantities of rubidium found in Lake Majeur sedimentary infills indicate drier climatic periods, such as from AD 1975 to AD 1982, during which water reservoirs were particularly in demand. Inversely, before the dam was built, rubidium fluctuations were correlated with wetter conditions and hydrological events were recorded as sandy layers deposited by canyon reactivation, synchronous with European climatic deterioration phases. We notably document that the Mediaeval Climate Anomaly was interrupted by some humid periods dated $c$. AD 940, AD 1080, AD II00 and AD 1250. We also date the onset of the 'Little Ice Age' C. AD I360 and identify that this period was wetter after C. AD I500.
\end{abstract}

\section{Keywords}

hydropower, lake sediment, mid-late Holocene, Pyrenees, soil erosion, trophic state

Received 6 February 2013; revised manuscript accepted 28 July 2013

\section{Introduction}

During the past century, the number of hydroelectric reservoirs drastically increased (Rosenberg et al., 1997), particularly in the French Pyrenees (Baran et al., 1995). Numerous studies have shown that such constructions induce disturbances to the Pyrenean river ecosystems (Baran et al., 1995; Lagarrigue et al., 2001; Lauters, 1992), suggesting that other natural systems could also be affected. Lacustrine sediments recording natural hazards and human activities are particularly relevant in assessing the consequences of future interventions on lacustrine systems. Some studies focused on the consequences of hydropower reservoirs (Anselmetti et al., 2007; Finger et al., 2007; Wirth et al., 2011) demonstrating that dams could be highly problematic considering present global change since such practices affect and modify natural processes in lacustrine environments depending on the management of the construction (pumping, lake-level regulation) (Delsontro et al., 2010; Jaun et al., 2007; Kunz et al., 2011).

In hydropower reservoirs, human-induced perturbations in lacustrine sediments are classically identified when focusing on sediment removal and chemical concentrations (Kunz et al., 2011)
'ISTO, UMR 7327 CNRS; Université d'Orléans; BRGM, IA rue de la Férollerie, 4507I Orléans Cedex 2, France

${ }^{2}$ GEODE, UMR 5602 CNRS/Université de Toulouse 2, Allée A.

Machado, 31058 Toulouse Cedex, France

${ }^{3}$ Laboratoire CEFREM, UMR5 I I0, Université de Perpignan via Domitia,

52 Avenue Paul Alduy, 66860 Perpignan Cedex, France

${ }^{4}$ Aix-Marseille Université, CNRS, IRD, Collège de France, CEREGE

UM34, I3545 Aix en Provence, France

${ }^{5}$ CNRS ECOLAB, 31326, Castanet Tolosan, France

${ }^{6}$ Université de Toulouse, INP, UPS, EcoLab (Laboratoire Ecologie Fonctionnelle et Environnement), ENSAT, Avenue de l'Agrobiopole, 31326 Castanet Tolosan, France

${ }^{7}$ TRACES, UMR 5608 CNRS/Université de Toulouse 2, 5, Allées A. Machado, 31058 Toulouse Cedex, France

${ }^{8}$ E.A. 6293 GéHCO, GéoHydrosystème COntinentaux, Université F. Rabelais de Tours, Département Géosciences-environnement, Faculté des Sciences et Techniques, Parc de Grandmont, 37200 Tours, France

\section{Corresponding author:}

Anaëlle Simonneau, ISTO, UMR 7327 CNRS; Université d'Orléans; BRGM, IA rue de la Férollerie, 4507I Orléans Cedex 2, France. Email: anaelle.simonneau@univ-tlse2.fr 

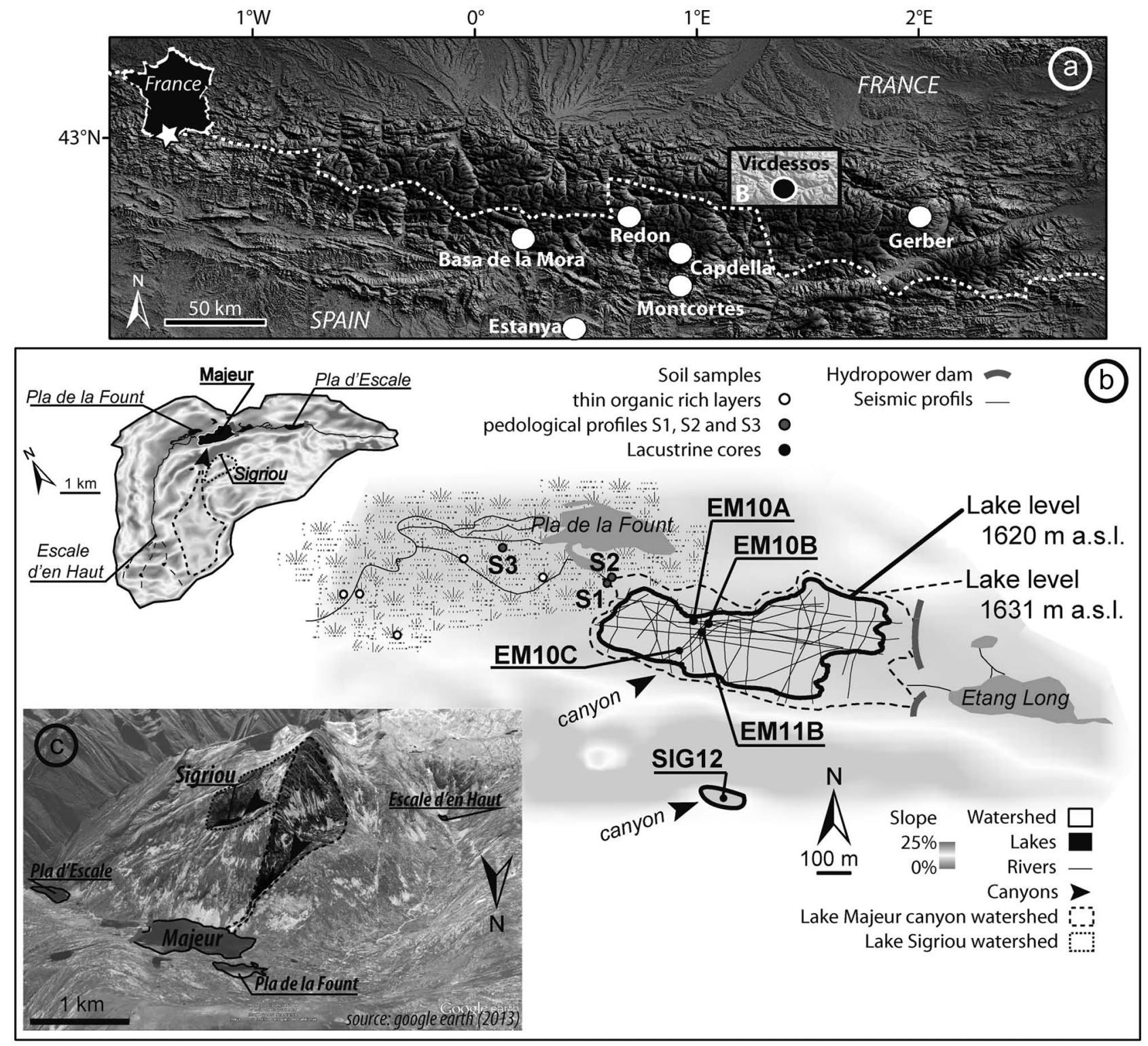

Figure I. (a) Localization of the Bassiès valley within the Vicdessos area, eastern Pyrenees. (b) The Bassiès valley is composed of numerous small lakes. Among them, Lake Majeur, used for hydropower production, and Lake Sigriou are further documented in the manuscript by acoustic mapping and sediment cores (EMIOA, EMIOB, EMIOC, EMIIB and SIGI2). In each lake, (c) an active canyon is clearly visible in satellite images, providing coarse material to lacustrine environments. Soil samples (SI, S2 and S3) discussed in the text are also located in (b).

or characterizing the optical properties of the water (Jaun et al., 2007). These disturbances can also be detected through organic geochemistry analysis as is done on classical lacustrine basins (Buillit et al., 1997; Noël et al., 2001). Lake Majeur is a natural lake of glacial origin surrounded by numerous peat bogs recording past anthropogenic signatures of the Holocene (Galop et al., 2011; 2013). It is therefore a suitable place to investigate both the pressure of climate and anthropogenic forcing on lacustrine systems and particularly recent human-induced lacustrine dynamics since the lake has been used for hydropower since AD 1907.

In this paper, we have studied Holocene lacustrine sequences retrieved along a north-south transect in Lake Majeur together with high-resolution seismic profiling of the basinfill and soil or rock samples from the surrounding watershed. This data set is compared to a core retrieved in the central part of Lake Sigriou, a small lake overhanging Lake Majeur (Figure 1). Continuous chemical analyses were used to describe the sedimentary units of the sequences and have been compared with punctual geochemical and petrographic characterizations of the organic matter. These analyses attempt to (1) characterize the minerogenic and organic sources of material brought into the lakes by runoff processes and to (2) identify whether they are climatic or humancontrolled. The aims of this study are to compare (1) the morphology of Lake Majeur basin before and after hydropower installations in order to quantify the consequences of recent hydro-damming on lacustrine environments in this part of the Pyrenees, and (2) the present-day basinfill dynamic with the natural one over the rest of the Holocene. In this context, Lake Sigriou is used as a reference site, where no hydropower activities are practised.

\section{Material and methods}

\section{Sampling site}

The hanging valley of Bassiès $\left(42^{\circ} \mathrm{N}\right.$, France) is part of the Upper Vicdessos valley (Figure 1a) located $95 \mathrm{~km}$ south of Toulouse. Its drainage basin $\left(15 \mathrm{~km}^{2}\right)$ is characterized by ice-smoothed granitic rocks resulting from the last glacial maximum (Delmas et al., 2011; Hérail et al., 1986; Jalut et al., 2010) and forming both (1) local steep slopes, in particular along the southern part of Lake 


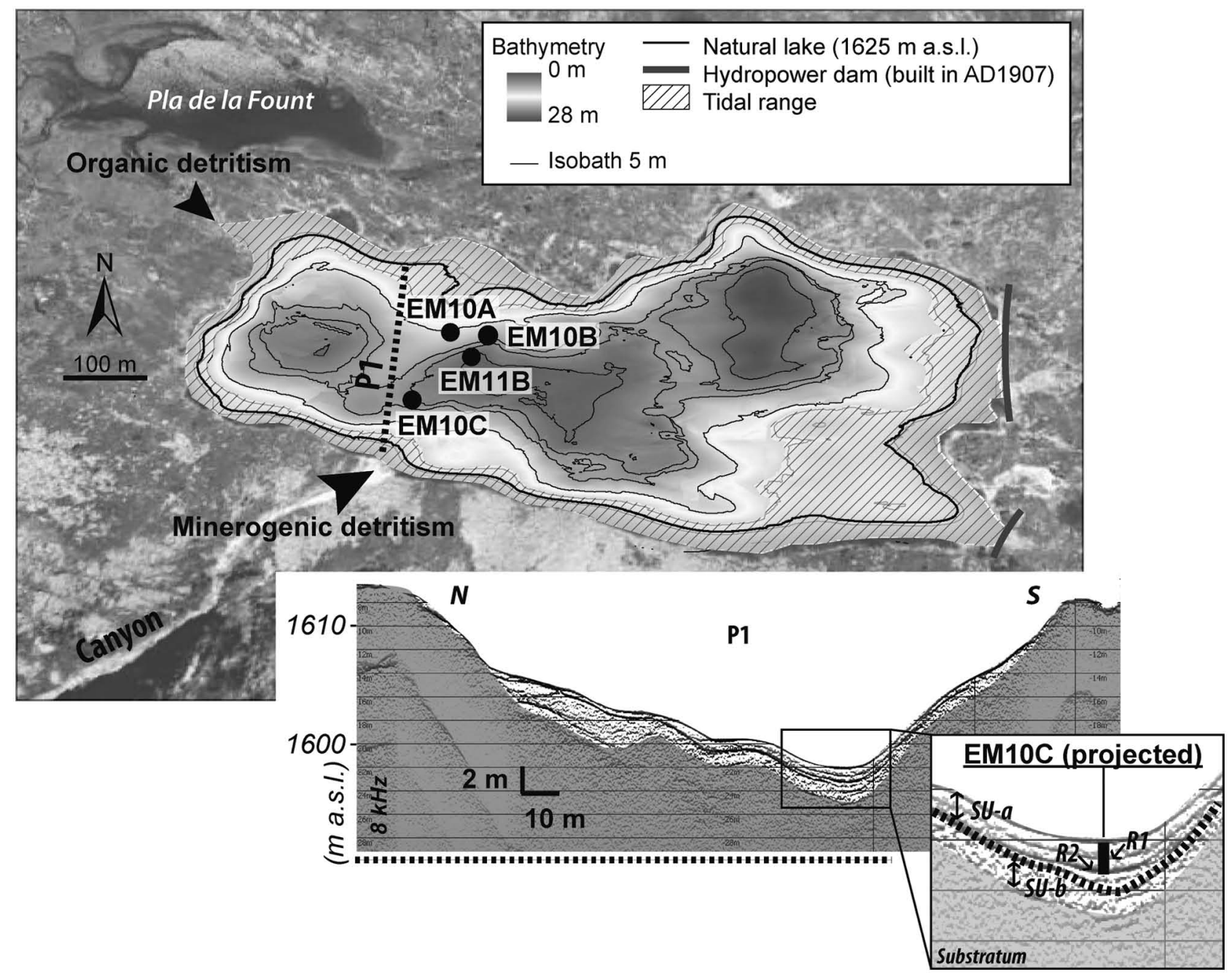

Figure 2. Characterization of Lake Majeur which is alimented by organic and minerogenic detritism on the northeast and the southern coast, respectively. The high-resolution bathymetric map is inferred from seismic data. As shown in a north-south seismic profile (PI), the sedimentary infill is characterized by two seismic units: SU-a and SU-b and several high-amplitude reflections, including RI and R2 discussed in the text.

Majeur and (2) flat areas within the rest of the catchment (Figure 1b) where swamps have developed. On the southern slopes of Lakes Majeur and Sigriou, two narrow canyons form two scree slopes composed of blocks, gravel and sand coming from the granitic dome (Figure 1b). The drainage basins of these active canyons are relatively small, limited to the high altitude part of the valley of Bassiès and disconnected from each other (Figure 1b). The stones present in each canyon are transported by torrential flow during intense rainfall or snowmelt affecting the upper part of the catchment. Other small and shallow lakes of glacial origin are present throughout the valley at different altitudes (Lake Escale d'en haut (1915 m a.s.1.), Lake Pla de la Fount (1655 m a.s.1.) and Lake Majeur (1632 m a.s.1.); Figure 1b). Lake Majeur $\left(42^{\circ} 45^{\prime} 40^{\prime \prime} \mathrm{N}-1^{\circ} 25^{\prime} 25^{\prime \prime} \mathrm{E}, 1630 \mathrm{~m}\right.$ a.s.l.; Figure $\left.1 \mathrm{~b}\right)$ is the largest basin $\left(0.2 \mathrm{~km}^{2}, 700 \mathrm{~m}\right.$ long and $300 \mathrm{~m}$ width $)$ of this valley. It is located downstream from numerous swamps and particularly from a large peat bog dated from 750 cal. yr BP (Galop, 1998) upstream from Lake Pla de la Fount (Figure 1b). Since AD 1907, the water-table of the natural basin of Lake Majeur has risen by 6 $\mathrm{m}$ (Figures $1 \mathrm{~b}$ and 2 ). Two dams regulate this water-table, draining off the water from the basin, naturally filled by rainfall and snowmelt. The artificial lake level thereby fluctuates from $-4 \mathrm{~m}$ during low lake-level stages and drier summers to $+6 \mathrm{~m}$ during highstand periods (from $1620 \mathrm{~m}$ a.s.l. to $1631 \mathrm{~m}$ a.s.1., respectively; Figures $1 \mathrm{~b}$ and 2). Lake Sigriou $\left(42^{\circ} 45^{\prime} 17^{\prime \prime} \mathrm{N}-1^{\circ} 25^{\prime} 20^{\prime \prime} \mathrm{E}\right.$, $1995 \mathrm{~m}$ a.s.l.; Figure 1b) stands on the southern shoreline of Lake Majeur (Figure 1b). It is a very small basin $\left(0.1 \mathrm{~km}^{2}, 87 \mathrm{~m}\right.$ long and $165 \mathrm{~m}$ width) whose drainage basin is composed of blocks from the granitic dome with thin soils frequently restricted to one thin organic layer.

Lacustrine basinfills of the different systems present in the Vicdessos valley were imaged in July 2010 and September 2011, using a subbottom profiler INNOMAR SES-2000 from an inflatable boat, or an echosounder, and coupled with global positioning system (GPS) navigation (Figure 1b). This was during lowstand and highstand periods, respectively, for Lake Majeur (Figure 1b). Two frequencies were used ( $8 \mathrm{kHz}$ in 2010 and $10 \mathrm{kHz}$ in 2011) in order to optimize the resolution of the acoustic signal in the sedimentary infills and to select suitable locations for short gravity cores. One core was taken in the subaquatic delta of Lake Escale d'en Haut (Figure 1b), another one was collected in the central part of Lake Pla de la Fount (Figure 1b), one more was sampled in the middle of Lake Sigriou (SIG12: $42.75^{\circ} \mathrm{N}-1.42^{\circ} \mathrm{E}$; Figure 1b), and finally, four cores were retrieved following a north-south transect in Lake Majeur (EM10B: $42.7620^{\circ} \mathrm{N}-1.4223^{\circ} \mathrm{E}$; EM10A: $42.7620^{\circ} \mathrm{N}-1.4222^{\circ} \mathrm{E} ; \quad \mathrm{EM} 11 \mathrm{~B}: \quad 42.7617^{\circ} \mathrm{N}-1.4225^{\circ} \mathrm{E}$ and EM10C: $42.7614^{\circ} \mathrm{N}-1.4213^{\circ} \mathrm{E}$; Figures $1 \mathrm{~b}$ and 2) with an UWITEC coring device (in 2010) or a Bobcorer one (in 2011), operated from an inflatable boat.

In 2010 and 2011, two rocks representative of the granitic dome were sampled to estimate the local geochemical background of the area. Eight pedological profiles (soil samples; Figure 1) were also collected within the drainage basin of Lake Majeur, in flat areas favourable to the accumulation of organic 
matter. Most of them (white dots, soil samples; Figure 1b) are reduced to one thin organic-rich layer, which directly covers the granitic material and are not therefore considered as real pedological profiles. Profiles S2 and S3 (grey dots, soil samples; Figure $1 \mathrm{~b}$ ) are constituted of three sandy to silty-clayey layers and are rich in organic material and siliceous gravel. They are thus considered as histosols. The sandy profile S1 (grey dots, soil samples; Figure 1b) is, on the contrary, essentially composed of numerous siliceous gravels and blocks suggesting that it is more of a till deposit than a pedological profile.

\section{Sedimentology and age model}

Laboratory descriptions of cores EM10B, EM10A, EM11B and EM10C, retrieved from Lake Majeur, and core SIG12, sampled in the central part of Lake Sigriou (Figure 1b), were supported by nondestructive high-resolution elemental analyses performed with the X-ray fluorescence (XRF) core scanner (ITRAX, Cox Analytical Systems; Croudace et al., 2006) at Centre Européen de Recherche et d'Enseignement des Géosciences de l'Environnement (CEREGE). The high-resolution radiographic image was obtained and posttreated from the ITRAX using a chromium tube as the $\mathrm{X}$-ray source at $45 \mathrm{kV}$ and $40 \mathrm{~mA}$, with $600 \mathrm{~ms}$ of counting time. The relative abundance of elements, such as rubidium $(\mathrm{Rb})$ or phosphorous (P), was measured every $1 \mathrm{~mm}$ for cores EM10C, EM11B and EM10B and the upper $20 \mathrm{~cm}$ of core EM10A, at 5 $\mathrm{mm}$ for the base of core EM10A and every $2 \mathrm{~mm}$ for core SIG2012 (using a chromium tube as the X-ray source at $35 \mathrm{kV}$ and $40 \mathrm{~mA}$, with $15 \mathrm{~s}$ of counting time). The calibration of these relative abundances was performed by elemental analyses of lacustrine sediment with laser ablation-inductively coupled plasma-mass spectrometer (LA-ICP-MS) Elementar XR Thermo Specific, following the procedure described by Gratuze et al. (2001), Aries et al. (2001) and Motellica-Heino et al. (2001). A total of 54 samples from cores EM10B and EM11B and 15 samples from soils, river bed and rocks were selected for destructive geochemical analyses (minerogenic and organic geochemistry). For minerogenic geochemistry, solid samples were prepared as pressed pellets. Powder samples of $350 \mathrm{mg}$ were put under 8 metric tonne pressure, without added binder, to form $13 \mathrm{~mm}$ (diameter) $\times 1 \mathrm{~mm}$ (height) pellets. The repetition rate of the $266 \mathrm{~nm}$ wavelength laser was fixed to $10 \mathrm{~Hz}$. Calibration took place with certified artificial glass: NIST-610 and Corning B, and results were certified using two reference materials: PACS-2 and MESS-3 (National Institute of Standards and Technology, 2006). Measurements were replicated four times to validate the analytical precision of the technique. Two granitic rock samples were also analysed by ICP-MS after lithium metaborate fusion. Bulk geochemical study of the organic matter was obtained by Rock-Eval pyrolysis to characterize the organic content of natural samples by thermal cracking and to quantify the amount of hydrocarbons that escape from the studied sample. The total organic carbon (TOC; expressed in percentage and the hydrogen index $(\mathrm{HI}=(\mathrm{S} 2 * 100) / \mathrm{TOC}$ expressed in $\mathrm{mgHC} / \mathrm{g}$ TOC, Behar et al., 2001) are the two main parameters frequently used to characterize soil organic matter (Buillit et al., 1997; Di Giovanni et al., 1998; Disnar et al., 2003; Sebag et al., 2006) or to identify the organic matter origin in lacustrine environments (Ariztegui et al., 2001; Simonneau et al., 2013; Talbot and Livingstone, 1989). The TOC represents the amount of organic carbon in samples, and the HI corresponds to the chemical quality of the organic compounds. Its decrease indicates the oxidation of the matter in the sediment or a contribution of terrestrial material (Ramanampisoa and Disnar, 1994). Quantitative organic petrography was carried out on the same set of samples. It consists of an optical identification and quantification of the organic constituents present in a constant volume of sediment (1 $\mathrm{cm}^{3}$ ) or in $1 \mathrm{~g}$ of soil, after elimination of carbonate and silicate phases by hydrochloric and hydrofluoric attacks (Graz et al., 2010; Simonneau et al., 2013). Components are characterized by their optical properties (colour and reflectance), their forms (amorphous or figurative) and their origins (algal, phytoclastic or fossil, Tyson, 1995).

Age-depth models of each lacustrine core taken from Lake Majeur were established based on two methods: (1) radiometric markers $\left({ }^{210} \mathrm{~Pb},{ }^{214} \mathrm{~Pb}\left({ }^{226} \mathrm{Ra}\right.\right.$ daughter $)$ and artificial radionuclides $\left({ }^{137} \mathrm{Cs}\right.$ and $\left.{ }^{241} \mathrm{Am}\right)$, measured on core EM10B, every centimetre for the top $21 \mathrm{~cm}$ using gamma spectrometry in the Underground Laboratory of Ferrières (Laboratoire de mesure des faibles radioactivités (LAFARA)/Laboratoire d'Etudes en Géophysique et Océanographie Spatiales (LEGOS)/Observatoire Midi-Pyrénées), and (2) eight accelerator mass spectrometry (AMS) ${ }^{14} \mathrm{C}$ radiocarbon dates from terrestrial vegetal remains (two from EM10C core, three from EM11B core, one from EM10A core and two from EM10B core, performed at the Radiocarbon Laboratory in Poznan and at the Laboratoire de Mesure du Carbone 14 in Gif-sur-Yvette).

The age-depth model of SIG12 core, obtained from Lake Sigriou, was established based on four AMS ${ }^{14} \mathrm{C}$ radiocarbon dates from terrestrial vegetal remains. One date has been rejected for being too old and potentially reworked. For all sequences, calibrated ages were computed using the radiocarbon calibration curve of Reimer et al. (2009), and the resulting five independent age-depth models were interpolated as linear regressions for cores EM10B, EM10A, EM11B, EM10C and SIG12, respectively, using the clam model developed by Blaauw (2010).

\section{Results and interpretations}

\section{Lacustrine system's sediment infill and chronology}

Substratum morphology. The seismic profiles from Lake Escale d'en Haut (Figure 1b) revealed that its substratum morphology is mainly composed of granitic blocks leading to numerous acoustic diffractions and coarse sand absorbing the acoustic signal. In the lower altitude system of Lake Pla de la fount (Figure 1b), a large amount of biogenic gas resulting from the degradation of organic material is preventing any penetration of the acoustic signal in the entire basin. Finally, only the substratum morphology and the basinfill geometry of Lake Majeur are well imaged on the subbottom profiles. A high-resolution bathymetric map of Lake Majeur was also generated from the seismic data (Figure 1b). It highlights two rock bars attesting the glacial origin of the lake and delimiting three sub-basins from west to east, reaching a depth of 25, 26 and $28 \mathrm{~m}$, respectively (Figure 2). A north-south profile in the central sub-basin (P1; Figure 2) illustrates a stratified basinfill up to $6 \mathrm{~m}$ thick in the central part characterized by several highamplitude reflections within the upper stratified acoustic facies (SU-a; Figure 2), where R1 and R2 (Figure 1b) have been identified at a depth of approximately 50 and $100 \mathrm{~cm}$, respectively, below the lake floor interface. SU-a covers an acoustically chaotic to transparent facies (SU-b; Figure 2), typical of glacial deposits (Van Rensbergen et al., 1999), above the acoustic substratum where the signal is absorbed.

Stratigraphy of Lake Majeur sedimentary infill. The x-ray radiographies and the $\mathrm{Rb}$ (i.e. rubidium) content, chosen because it is both representative of the granitic dome present in the catchment area and characterized by the highest XRF amplitude in the sedimentary facies, led to define six sedimentary units within Lake Majeur lacustrine sediments (from U0 to U5, from base to top, respectively; Figure 3). U0, U1, U2 and U3 are only present in EM11B core, whereas U4 and U5 show coherent characteristics whatever the considered core (Figure 3). U0, U1, U2 and U3 are light grey silty to clayey facies defined by dense and fine-grained 


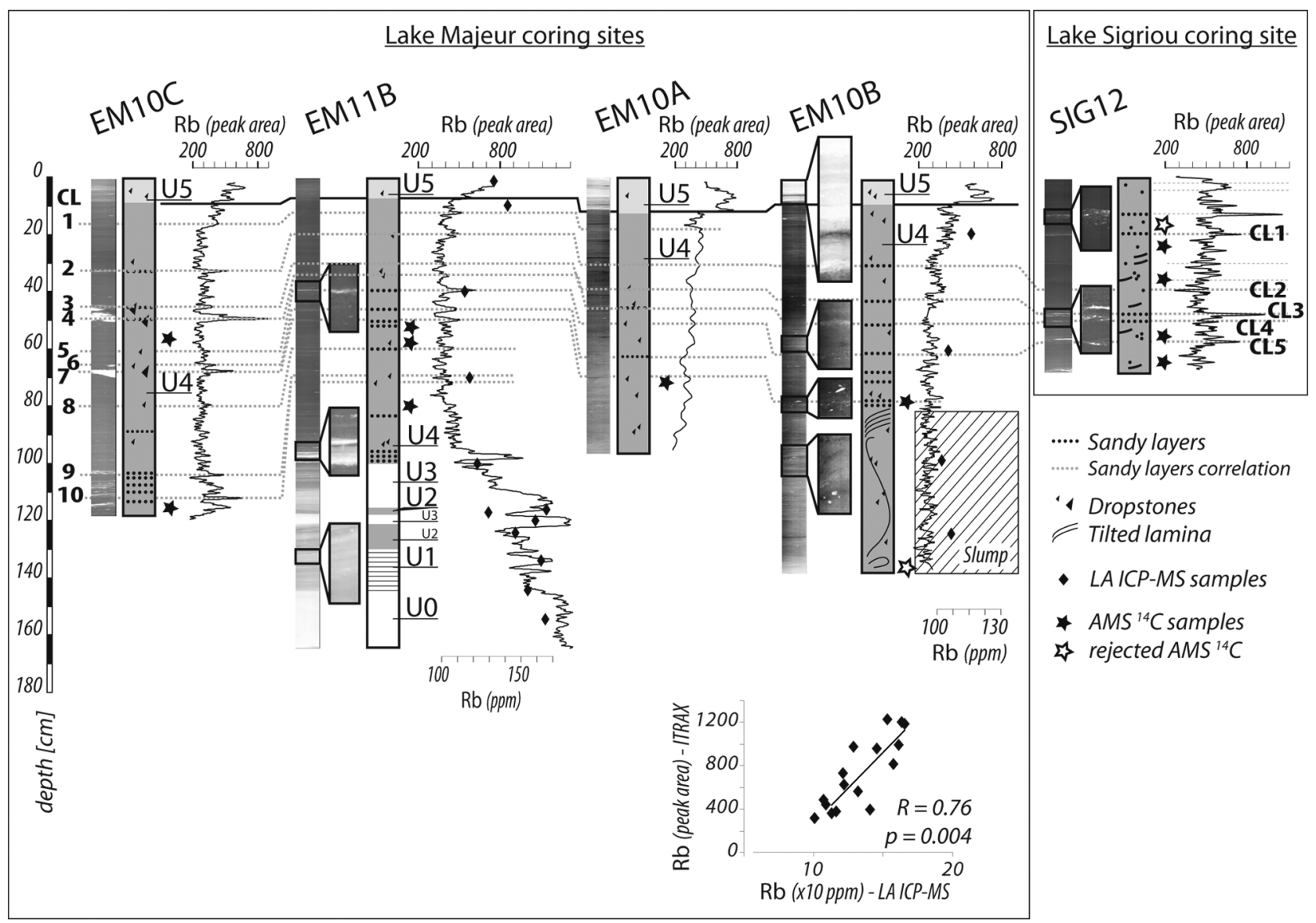

Figure 3. A south-north transect of lacustrine cores retrieved from Lake Majeur (from left to right: EMIOC, EMIIB, EMIOA and EMIOB) and core SIGI2, sampled in Lake Sigriou, is represented. Each core is characterized by high-resolution x-ray radiography (black and white image) and relative rubidium ( $\mathrm{Rb}$ ) abundance (expressed in peak area) whose calibration is done by punctual LA-ICP-MS measurements (black diamond) performed on core EMI IB.Whatever the core, these two parameters highlight the occurrence of coarse layers (CLI-CLI 0$)$, dropstones and a slump deposit affecting core EMIOB. White and black stars symbolize the locations of chronological controls detailed in Table I. LA-ICP-MS: laser ablation-inductively coupled plasma-mass spectrometry; CL: coarser layer;AMS: accelerator mass spectrometry.

material (lighter colour on x-ray radiographies; Figure 3). U0 and $\mathrm{U} 3$ are particularly rich in $\mathrm{Rb}$ (around 1200 peak area, equivalent to $180 \mathrm{ppm}$, except at the top of the second unit U3 where the signal is equal to 800 peak area, equivalent to $124 \mathrm{ppm}$ ), whereas $\mathrm{U} 1$, which is laminated, and $\mathrm{U} 2$, which is not laminated and darker than units $\mathrm{U} 0, \mathrm{U} 1$ and $\mathrm{U} 3$, are less rich in this element (approximately 1000 peak area, equivalent to $155 \mathrm{ppm}$ ). The transition between $\mathrm{U} 3$ and $\mathrm{U} 4$ is not dated, but available radiocarbon dates suggest that U4 covers at least the mid- and lateHolocene periods (Table 1 and Figure 4) and therefore suggests that units U3, U2, U1 and U0 were deposited during the Lateglacial and the early Holocene periods. Ongoing pollen analysis and radiocarbon dating should confirm such hypothesis. Preliminary pollen assemblage identifications, performed between 110 and $160 \mathrm{~cm}$ depth in EM11B core, clearly indicate a surrounding vegetation largely dominated by herbaceous taxa ( $c$. $65-68 \%$ of pollen sum) essentially composed of Poaceae, Artemisia, Chenopodium and Compositae, and low values of tree taxa (mainly Pinus) characteristic of the Lateglacial period (Jalut et al., 1996). U4 is not dense (darker colour on x-ray radiographies; Figure 3), not laminated, dark brown coloured, rich in macroscopic organic debris but relatively poor in $\mathrm{Rb}$ (350 peak area, approximately $100 \mathrm{ppm}$ ). Only EM10B core is characterized below a depth of $85 \mathrm{~cm}$ by the occurrence of tilted lamina observed on the x-ray radiography and large quantities of gravel (hatched area; Figure 3). This specific facies is typical of slump deposits resulting from lacustrine sediment remobilization (Mulder and Cochonat, 1996). In addition, U4 is interrupted by numerous sandy layers and dropstones identified by eyedescriptions and lighter colours on $\mathrm{x}$-ray radiographies (Figure 3). A total of 10 coarser layers (CLs) have been identified by eye-descriptions at different depths below the lake floor in the four cores and numbered from CL1 to CL10, from top to base, respectively (Figure 3 ). Each CL further corresponds to higher concentrations in $\mathrm{Rb}$ (from 200 to 900 peak area, that is, from 96 to $148 \mathrm{ppm}$; Figure 3). CLs, and their associated Rb peaks, are particularly present and more easily identified by the Rb content within EM10C and EM11B cores, which are proximal to the active canyon affecting the southern shore of the lake (Figures $1 \mathrm{~b}$ and 2). In addition, CL4 and CL10 match the two acoustic reflections R1 and R2, respectively, observed on seismic profiles (Figures 2 and 3). Finally, U5 is composed of dense un-laminated clayey material rich in $\mathrm{Rb}$ (from 500 to 800 peak area, equivalent to 118-140 ppm; Figure 3) producing a lighter colour on the $\mathrm{X}$-ray radiographies.

Stratigraphy of Lake Sigriou sedimentary infill. As for Lake Majeur coring sites, $\mathrm{x}$-ray radiography and rubidium content were analysed on SIG12 core, obtained from Lake Sigriou. SIG12 core is composed of one sedimentary unit, which appears as sedimentary unit U4, previously described in Lake Majeur (Figure 3). This unit is not dense, not laminated, dark-coloured and rich in macroscopic organic debris. This facies is frequently interrupted by sandy layers similar to the ones observed in Lake Majeur sediments (Figure 3 ) and characterized both by a lighter colour on $\mathrm{X}$-ray radiographies and higher $\mathrm{Rb}$ content (Figure 3 ). 
Table I. Radiocarbon $\left({ }^{14} \mathrm{C}\right.$ AMS $)$ and radiometric or artificial radionuclides measurements $\left({ }^{210} \mathrm{~Pb},{ }^{137} \mathrm{Cs}\right.$ and $\left.{ }^{241} \mathrm{Am}\right)$ obtained from Lake Majeur sediment cores EMIOA, EMIOC, EMIOB and EMIIB. Age calibration was done using sets by Reimer et al. (2009). Black stars indicate the two reworked vegetal remains that were not included in age-depth models.

\begin{tabular}{|c|c|c|c|c|c|}
\hline \multicolumn{6}{|l|}{${ }^{14} \mathrm{C}$ AMS } \\
\hline Material & Cores & Depths (cm) & Laboratory & Radiocarbon ages (BP) & Calibrated ages (cal. BP) \\
\hline \multirow[t]{13}{*}{ Vegetal remains } & EMIOC & 58 & Poz-48289 & $1285 \pm 35$ & $1230 \pm 60$ \\
\hline & & 118 & Poz-42019 & $4445 \pm 35$ & $5020 \pm 65$ \\
\hline & EMIIB & 55 & SacA $27597^{*}$ & $2225 \pm 30$ & $2245 \pm 60$ \\
\hline & & 57 & Poz-48290 & $2130 \pm 30$ & $2080 \pm 80$ \\
\hline & & 82 & Poz-48293 & $5230 \pm 120$ & $6010 \pm 270$ \\
\hline & EMIOA & 71.5 & Poz-42006 & $2030 \pm 30$ & $1990 \pm 70$ \\
\hline & EMIOB & 81.5 & Poz-38193 & $1880 \pm 40$ & $1805 \pm 90$ \\
\hline & & 138 & Poz-38192* & $500 \pm 30$ & $525 \pm 25$ \\
\hline & SIGI 2 & 17.5 & Poz-50347* & $470 \pm 30$ & $515 \pm 20$ \\
\hline & & 25.5 & Poz-52348 & $370 \pm 60$ & $370 \pm 115$ \\
\hline & & 35.5 & Poz-52350 & $390 \pm 60$ & $390 \pm 115$ \\
\hline & & 55.5 & Poz-5235I & $1310 \pm 30$ & $1310 \pm 60$ \\
\hline & & 65.5 & Poz-52353 & $1590 \pm 90$ & $1590 \pm 175$ \\
\hline \multicolumn{6}{|l|}{ Radionuclides } \\
\hline Material & Cores & Depths (cm) & Unsupported ${ }^{210}(\mathrm{~Bq} / \mathrm{kg})$ & ${ }^{137} \mathrm{Cs}(\mathrm{Bq} / \mathrm{kg})$ & ${ }^{241} \mathrm{Am}(\mathrm{Bq} / \mathrm{kg})$ \\
\hline \multirow[t]{11}{*}{ Bulk } & EMIOB & $0-1$ & $8133 \pm 149$ & $103.04 \pm 1.61$ & $2.21 \pm 0.47$ \\
\hline & & $\mathrm{I}-2$ & $5215 \pm 138$ & $113.35 \pm 1.83$ & $1.89 \pm 0.50$ \\
\hline & & $2-3$ & $2969 \pm 115$ & $74.03 \pm 1.48$ & $1.64 \pm 0.47$ \\
\hline & & $3-4$ & $1700 \pm 104$ & $24.28 \pm 0.86$ & \\
\hline & & $4-5$ & $1649 \pm 97$ & $|5.00 \pm 0.7|$ & \\
\hline & & $5-6$ & $585 \pm 87$ & $3.85 \pm 0.43$ & \\
\hline & & $6-7$ & $653 \pm 89$ & $1.29 \pm 0.35$ & \\
\hline & & $7-8$ & $366 \pm 88$ & $0.59 \pm 0.40$ & \\
\hline & & $8-9$ & $369 \pm 71$ & $0.03 \pm 0.31$ & \\
\hline & & $9-10$ & $334 \pm 67$ & $0.38 \pm 0.31$ & \\
\hline & & $10-11$ & $185 \pm 64$ & $0.22 \pm 0.32$ & \\
\hline
\end{tabular}

AMS: accelerator mass spectrometry.

Chronology of the sedimentary infill of Lake Majeur. Modern agedepth model of Lake Majeur is based on the unsupported ${ }^{210} \mathrm{~Pb}$ activity (calculated using the ${ }^{214} \mathrm{~Pb}$ activity) from EM10B core (Table 1; Figure 4; upper panel). Excess ${ }^{210} \mathrm{~Pb}$ was used to estimate the age-depth relationship using constant rate sedimentation (CRS) and constant initial concentration (CIC) models (Appleby and Oldfield, 1978; Le Roux and Marshall, 2011). Both models give similar results, and we will discuss the results further using the ${ }^{210} \mathrm{~Pb}$ CRS model (black full line; Figure 4, upper panel). The total excess ${ }^{210} \mathrm{~Pb}$ and ${ }^{137} \mathrm{Cs}$ inventories are 22 and $5.5 \mathrm{kBq} / \mathrm{m}^{2}$, respectively. The artificial radionuclide ${ }^{137} \mathrm{Cs}$ shows a slight increase between 1 and $2 \mathrm{~cm}$ depth (Table 1; Figure 4, upper panel) corresponding to an age of $\mathrm{AD} 1960 \pm 5$ according to the ${ }^{210} \mathrm{~Pb}$ CRS model. This signal can therefore be correlated to the atmospheric nuclear weapon tests culminating in AD 1963 in the Northern Hemisphere and in the Pyrenees (Roussel-Debet et al., 2007). No further ${ }^{137} \mathrm{Cs}$ peaks have been detected afterwards, suggesting that the Chernobyl accident in $\mathrm{AD} 1986$ is not well recorded in this part of the Pyrenees. This is in accordance with work of Roussel-Debet et al. (2007). This interpretation is further supported by the occurrence of ${ }^{241} \mathrm{Am}$ in the two upper centimetre of EM10B core (Table 1; Appleby and Oldfield, 1978; Guyard et al., 2007; Nomade et al., 2005).

The transition between the sedimentary units U5 and U4 occurred at approximately $7 \mathrm{~cm}$ below the lake floor in EM10B core. Using the CRS model (black full line; Figure 4, upper panel), the mean accumulation rate of U5 in EM10B core is equal to $0.7 \mathrm{~mm} / \mathrm{yr}$. The transition between U5 and U4 is therefore dated around $\mathrm{AD} 1910 \pm 2$, which is almost synchronous with the beginning of the hydropower activities in Lake Majeur dated at AD
1907. It suggests that the abrupt shift from the sedimentary unit U4 to U5, recorded in whichever core and its location (Figure 3), results from hydroelectric activities. Using the transition between U5 and U4 as a stratigraphic marker for core-to-core correlations (black line; Figure 3), the mean accumulation rate in U5 is equalled to $1 \mathrm{~mm} / \mathrm{a}$. The transition between the sedimentary units U5 and U4 was thereby used as a common chronological control in each core.

For the rest of the Holocene period, four independent linear age-depth models have been generated for cores EM10C, EM11B, EM10A and EM10B, depending on the vegetal remains found within each core (Table 1; Figure 4, lower panel). For the agedepth models of EM10B and EM11B cores, two dates (SacA 27597* and Poz-38192*, respectively, Table 1) have been rejected for being too old and potentially reworked. It is further supported by the slump facies identified at the base of EM10B core (hatched area; Figure 3), thereby dated approximately $1800 \mathrm{cal}$. BP. Mean accumulation rates have been calculated for each core: they are equal to $0.3 \mathrm{~mm} / \mathrm{a}$ for cores EM10C, EM10A and EM10B and increase from 0.06 to $0.3 \mathrm{~mm} / \mathrm{a}$, after approximately $2000 \mathrm{cal}$. BP, for EM11B core. These linear regressions allow calculating four independent ages for the 10 CLs (i.e. CL1-CL10; Figure 4, lower panel) previously identified in cores by stratigraphies (Figure 3). These 10 phases of sandy or gravel deposits are synchronous whatever the considered core and within the age-depth model errors, highlighting the consistency of our core-to-core correlations. These minerogenic detrital layers are dated approximately to $4760 \pm 170$, $4210 \pm 90,2640 \pm 95,1830 \pm 80,1690 \pm 75,1380 \pm 80(\mathrm{AD} 570 \pm$ $80), 1010 \pm 75(\mathrm{AD} 940 \pm 75), 870 \pm 50(\mathrm{AD} 1080 \pm 50), 590 \pm 40$ $(\mathrm{AD} 1360 \pm 40)$ and $230 \pm 15 \mathrm{cal}$. $\mathrm{BP}(\mathrm{AD} 1710 \pm 15)$. 


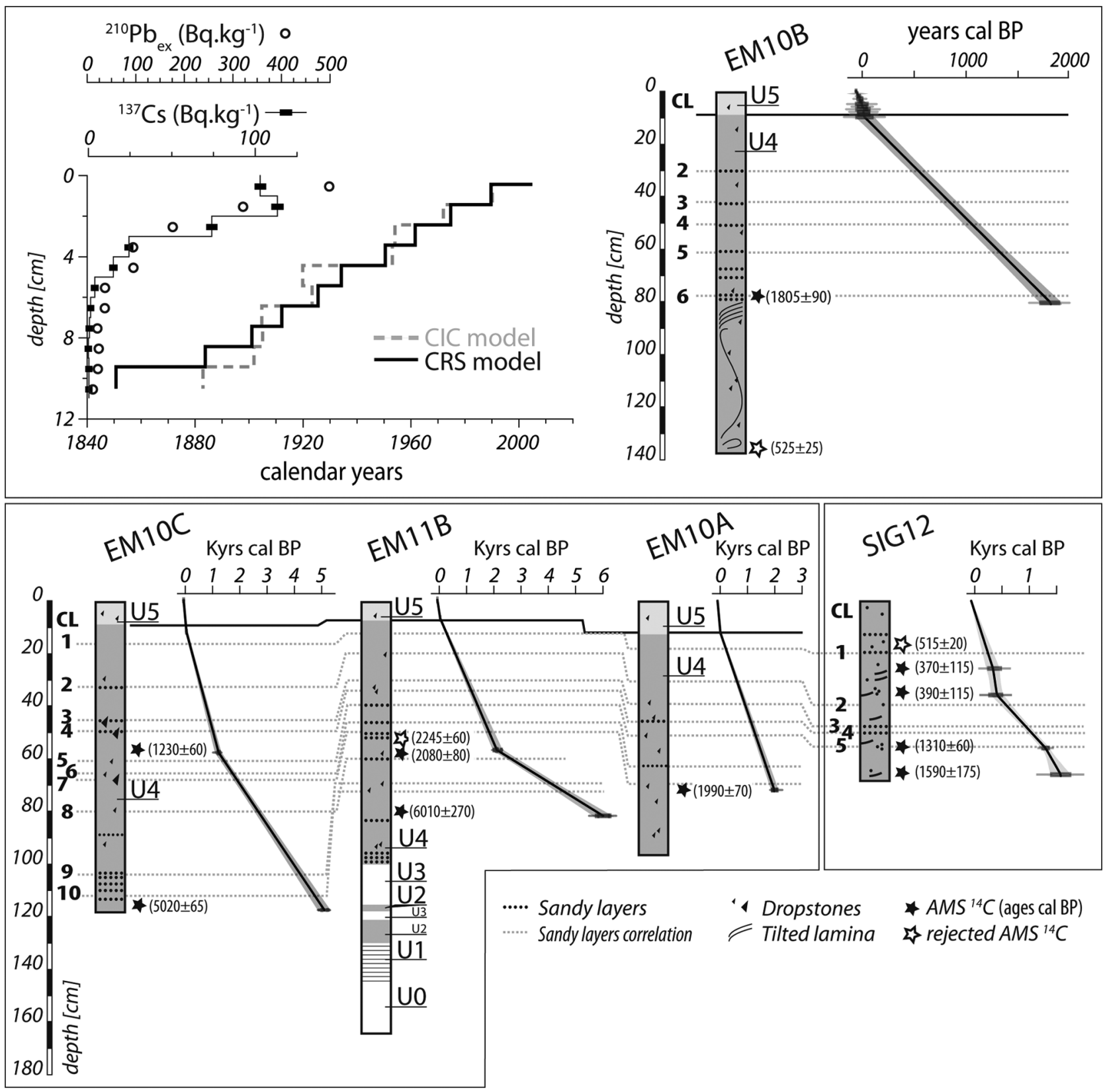

Figure 4. Age-depth model of cores EMIOB, EMIOC, EMIIB, EMIOA and SIGI 2 based on radiometric markers $\left({ }^{210} \mathrm{~Pb}\right)$, artificial radionuclides $\left({ }^{137} \mathrm{Cs}\right)$ and radiocarbon dates allowing the stratigraphic correlations of $\mathrm{CLs}(\mathrm{CLI}-\mathrm{CLIO})$ in several cores from Lake Majeur and Lake Sigriou. In core EMIOB from Lake Majeur, the application of a CRS model (black full line) based on ${ }^{210} \mathrm{~Pb}$ data is supported by the occurrence of artificial radionuclides $\left({ }^{137} \mathrm{Cs}\right.$ and $\left.{ }^{241} \mathrm{Am}\right)$ as discussed in the text and allows dating the transition from unit U5 and U4 in Lake Majeur at AD $1910 \pm 2$. In the lower panel, individual linear regression of cores EMIOC, EMIIB, EMIOA and SIGI 2 based on radiocarbon dating is represented, providing independent ages for each CLs identified in both lakes.

CRS: constant rate sedimentation; $\mathrm{CL}$ : coarse layer;AMS: accelerator mass spectrometry.

Chronology of the sedimentary infill of Lake Sigriou. For the agedepth model of SIG12 core, one date (Table 1) has been rejected. Based on linear regression, the resulting age-depth model covered the last 1600 years, and mean sedimentation rates increase from $0.25 \mathrm{~mm} / \mathrm{a}$ between 1590 and $390 \mathrm{cal}$. BP to $1.4 \mathrm{~mm} / \mathrm{a}$ between 390 and $370 \mathrm{cal}$. BP, and decrease to $0.6 \mathrm{~mm} / \mathrm{a}$ afterwards. Such results enable the calculation of ages for the sandy layers identified in the SIG12 core (Figure 3). They have been dated to $\mathrm{AD} 610 \pm 55, \mathrm{AD} 910 \pm 55, \mathrm{AD} 1020 \pm 60, \mathrm{AD} 1380 \pm 95, \mathrm{AD}$ $1535 \pm 115, \mathrm{AD} 1575 \pm 85, \mathrm{AD} 1695 \pm 75, \mathrm{AD} 1805 \pm 45$ and between $\mathrm{AD} 1925 \pm 20$ and $\mathrm{AD} 1990 \pm 5$ (Figure 4). Those dated to $\mathrm{AD} 610 \pm 55, \mathrm{AD} 910 \pm 55, \mathrm{AD} 1020 \pm 60, \mathrm{AD} 1380 \pm 95$ and $\mathrm{AD} 1695$ \pm 75 are therefore synchronous with coarse layers CL1, CL2, CL3, CL4 and CL5 previously identified and dated in Lake Majeur (Figures 3 and 4).
Minerogenic and organic signatures of the rocks and the soils

The two granitic rock samples analysed demonstrate that the granitic dome present throughout the Vicdessos valley is essentially composed of zirconium (149 and $137 \mathrm{ppm}$, respectively), Rb (223 and $155.5 \mathrm{ppm}$, respectively) and barium (683 and 658 ppm, respectively). Under weathering conditions, these three elements should therefore be released through runoff processes and trapped into the lake. This is further supported by the good match between the sandy layers or the occurrence of gravel and $\mathrm{Rb}$ peaks identified throughout the lacustrine sedimentation of Lake Majeur (Figure 3).

Soils (black crosses; Figure 5a) are characterized by various TOC contents (from $1.57 \%$ to $49.51 \%$ ) and HI values fluctuating between 120 and $565 \mathrm{mgHC} / \mathrm{g}$ TOC, that is, between the 

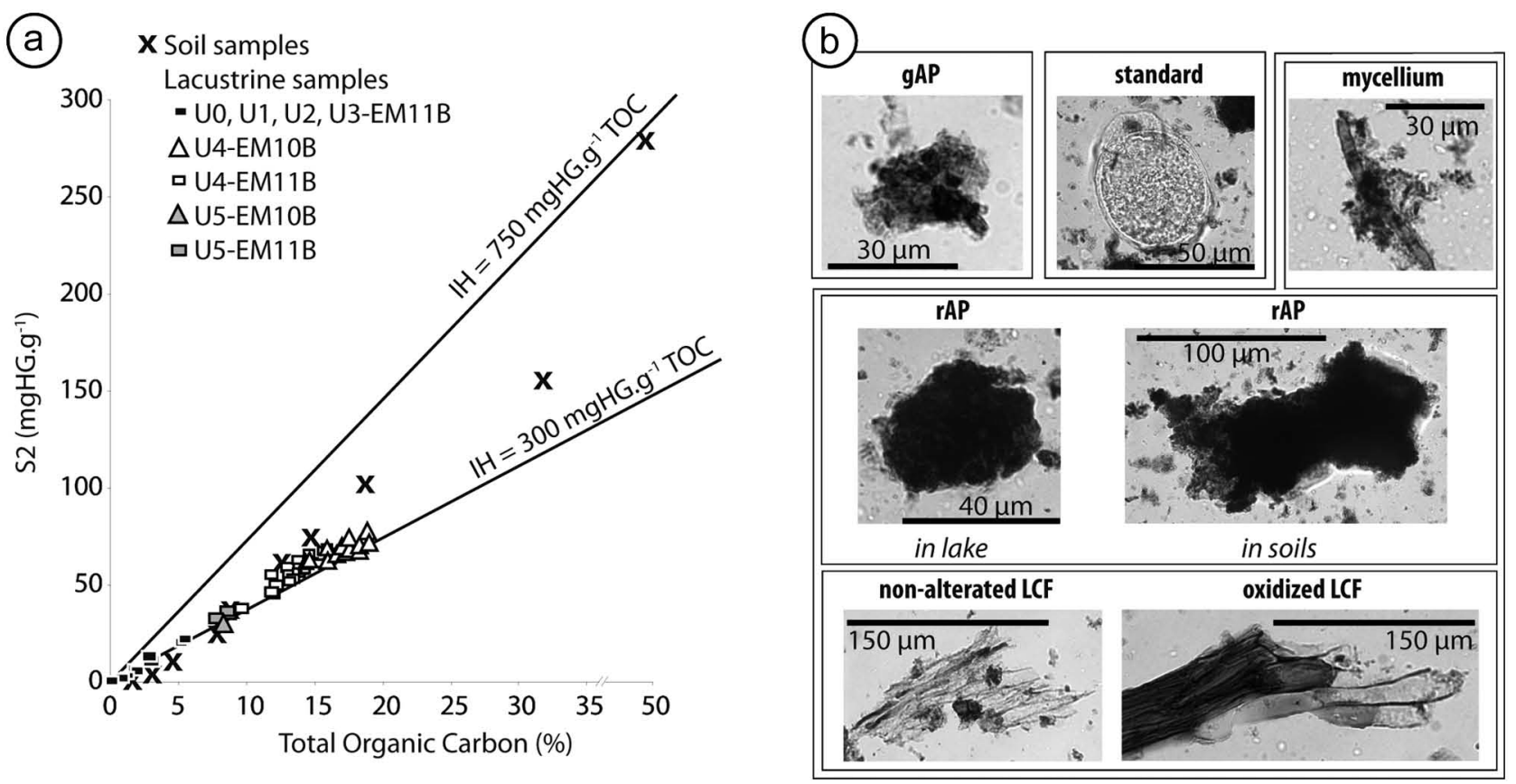

Figure 5. (a) Rock-Eval pyrolysis results from soil (black crosses) and lacustrine sediment (others) samples are represented through a $\mathrm{S} 2$ ( $\mathrm{mgHC} / \mathrm{g}, \mathrm{S} 2=\mathrm{HI} * \mathrm{TOC}$ ) versus TOC (\%) diagram. Two lines corresponding to $\mathrm{HI}$ equal to 750 and $300 \mathrm{mgHC} / \mathrm{g} \mathrm{TOC}$, respectively, are also traced in order to delimitate the algal and the terrestrial poles, respectively. (b) Soil and lacustrine samples are also characterized by quantitative organic petrography where gAP are only found in lacustrine samples whereas mycelium, rAP and LCF are observed in lacustrine and soil samples.

HI: hydrogen index;TOC: total organic carbon; gAP: grey amorphous particles; rAP: red amorphous particles; LCF: ligno-cellulosic fragments.

algal pole defined by Talbot and Livingstone (1989) and the terrestrial one (Buillit et al., 2001). Such high HI values in terrestrial samples correspond to a high contribution of fresh organic matter typical of peat environments (Disnar et al., 2008). Two groups of organic components have been identified in these soils (Figure 5b): (1) nonpollen microfossil particles with colloidal red amorphous particles (rAP) defined by diffuse external limits and without internal structures, ligno-cellulosic fragments (LCF) and mycelium particles and (2) pollen microfossil particles represented by spores and pollens. rAP are similar to the ones observed in soils or lacustrine environments by Noël et al. (2001), Sebag et al. (2006) or Simonneau et al. (2013), and correlate to pedological origin. Histosols are essentially comprised of rAP (Figure 5b).

\section{Organic signatures of the lacustrine sediment from Lake Majeur}

Lacustrine sediment samples from EM11B and EM10B cores are defined by various TOC contents (from $0.05 \%$ to $19.05 \%$ ) and $\mathrm{HI}$ values (from 50 to $465 \mathrm{mgHC} / \mathrm{g}$ TOC) (Figure 5a). Measurements performed in the sedimentary units U0, U1, U2 and U3 (black squares; Figure 5a) are characterized by a progressive increase in the organic carbon content (from $0.05 \%$ to $6 \%$ ) and of the HI values (from 50 to $380 \mathrm{mgHC} / \mathrm{g}$ TOC; Figure 5a). This strongly contrasts with the U4 sedimentary unit, defined by TOC values superior to $12 \%$ and $\mathrm{HI}$ values superior to $400 \mathrm{mgHC} / \mathrm{g}$ TOC (white squares and triangles; Figure 5a). In U5, TOC values average $8 \%$ and $\mathrm{HI}$ values are superior to $420 \mathrm{mgHC} / \mathrm{g}$ TOC (grey squares and triangles; Figure 5a). Quantitative organic petrography analyses have demonstrated that all lacustrine samples only differ from the watershed ones by the presence of grey amorphous particles (gAP; Figure 5a) corresponding to products of algal production in the lake waters (Patience et al., 1996). HI values therefore correspond to the mixture of autochthonous and allochthonous material in the background lacustrine sediment. The lowest values measured within units $\mathrm{U} 0, \mathrm{U} 1, \mathrm{U} 2$ and $\mathrm{U} 3$ suggest a higher degree of oxidation of the organic matter.

Focusing on the two uppermost sedimentary units, U4 and U5, we document that the proportion of autochthonous and allochthonous material differs. Quantitative organic petrography results show that algal production represents only $40 \%$ of the sedimentary organic matter within unit U4 (Figure 6a), whereas it increases up to $75 \%$ through unit U5 (Figure 6a). Based on their organic carbon contents (Figure 5a), both units could be defined as gyttjas, which are organic-rich lacustrine sediments (Hansen, 1959). Their different composition suggests, however, that unit U4 is in fact a dy, corresponding to organic-rich lacustrine sediments, mostly composed of allochthonous supply, rather than a gyttja, essentially composed of autochthonous material (Nauman, 1922).

\section{Discussion}

Impacts of the hydroelectric activities on Lake Majeur sedimentary infill

At Lake Majeur, hydroelectric activities date from AD 1907 and have consisted of regular perturbations to the lake level affecting the natural limit of the basin (black thick line; Figure 2), depending on hydroelectricity production or water necessity. Considering the water-level between artificial highstand and lowstand periods (i.e. from $1620 \mathrm{~m}$ a.s.l. to $1631 \mathrm{~m}$ a.s.l., respectively, in Figure 1b, and hatched area in Figure 2), we calculate that 78,635 $\mathrm{m}^{2}(37 \%)$ of the lacustrine surface is affected by hydroelectric activities. Below this surface, lacustrine sediments are constituted of minerogenic light-coloured clayed deposits similar to those described through the sedimentary units U0, U1, U2 and U3 particularly rich in $\mathrm{Rb}$ content (Figure 3 ). The recent abrupt rise in $\mathrm{Rb}$ dating from $\mathrm{AD} 1910 \pm 2$, and identified in each core (Figure 3 ), could therefore result from the remobilization of older sediments of glacial origin. The lacustrine slopes can be particularly mobilized during water-level fluctuations in the lake which 

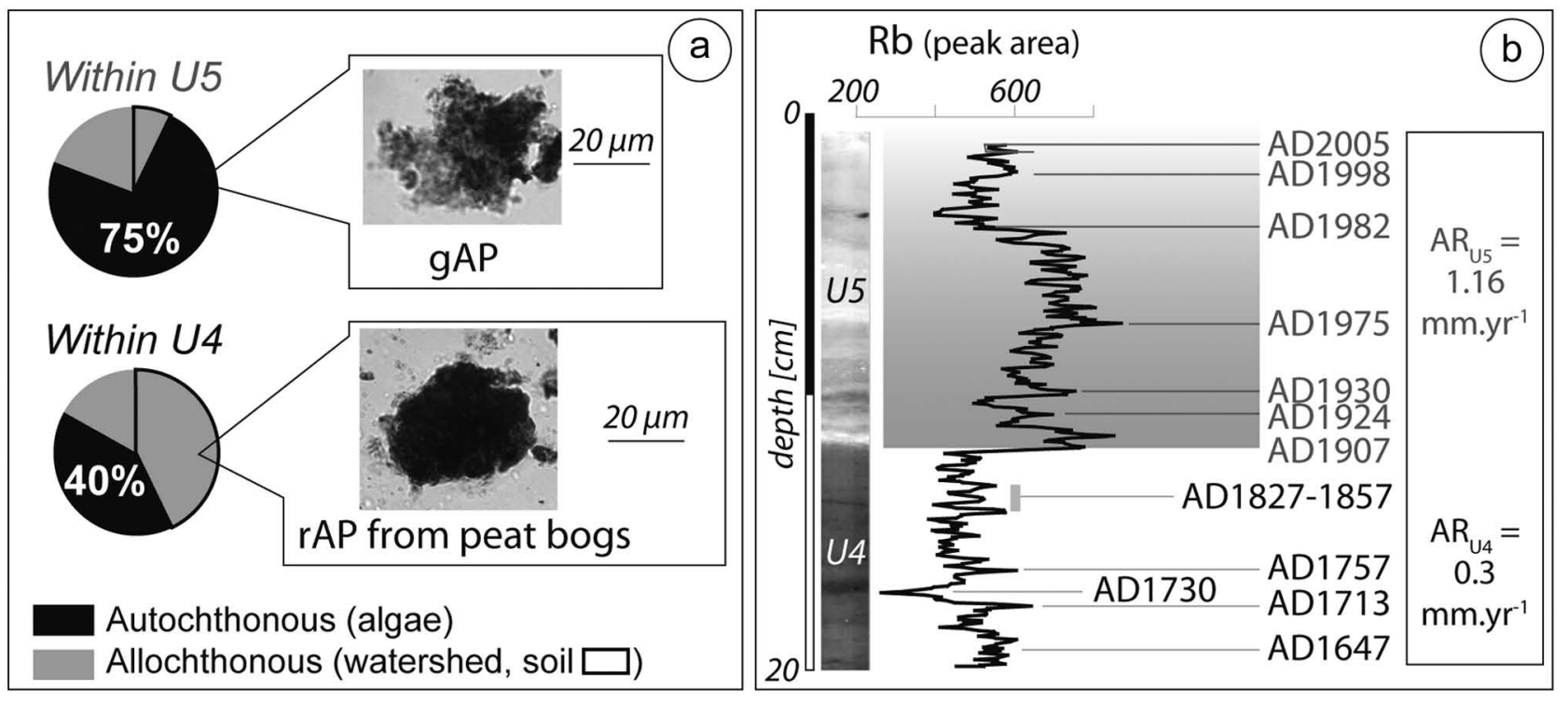

Figure 6. Detailed characteristics of sedimentary units U4 and U5 in core EMIOA. (a) The organic compositions of the two sedimentary units are illustrated, demonstrating that $U 4$ is mainly constituted of allochthonous particles (soil particles, rAP), while U5 is essentially made of autochthonous ones (algae, gAP). (b) The rubidium ( $\mathrm{Rb}$ ) relative abundance in the upper part of core EMIOA is also represented in function of the depth below the lake floor and each remarkable peak is dated based on the application of a mean AR in each sedimentary unit (U4 and U5). AR: accumulation rate; gAP: grey amorphous particles; rAP: red amorphous particles.

modify the water pressure and thus the sediment coherence and erodibility. The synchronicity between the abrupt increase in $\mathrm{Rb}$ content in lacustrine sediment and the beginning of anthropogenic lake-level regulations during hydroelectric activities seems to indicate that both the higher minerogenic supplies (Figures 3 and $6 \mathrm{~b}$ ) and the abrupt increase of the accumulation rates (AR, Figure 6b), which are fourfold in EM10A core between U4 and U5, result from dam activities. Higher sediment input in lacustrine sediments has also been associated with hydroelectric activities, and notably with lake-level fluctuations, by Wirth et al. (2011) in Switzerland. This suggests that the natural sedimentary dynamic of the lake has thus been significantly modified during humaninduced water-table regulations of the lake, essentially through the remobilization of the pre-Holocene lacustrine sediments from the edges of the lake towards the lake basin (Figure 2).

\section{The lacustrine organic composition as an indicator of lake sediment dynamic}

The previous century: from $A D 1910$ to present-day. After $A D$ 1910 , the sedimentary organic matter was essentially composed of algae compounds (Figure 6a). This period coincides with the beginning of hydroelectric activities dating from $\mathrm{AD} 1907$ (déjà dit - redundant). During the past century, Lake Majeur was also used for fish breeding, and the associated nutrients loading could favour algae production and lacustrine enrichment (Reynolds et al., 2000). However, no increase of phosphorous content has been measured by LA-ICP-MS, in unit U5 in comparison to unit U4. The synchronicity between the abrupt shift of lake trophic levels and the beginning of hydro-damming suggests that both high minerogenic supply and water-table regulations favoured algae production releasing sedimentary organic matter or favouring warmer water during extended lowstand periods. Hydropower production at Lake Majeur consists of emptying the lake during the dry season or at other times when electricity demand is high, after which the basin is naturally filled again by autumnal and winter rainfall and snowmelt. This could thus explain why Anselmetti et al. (2007) and Finger et al. (2007) did not notice any lacustrine trophic level modification associated with hydropower. Daily pump storage activities disturb the water-column stratigraphy and can therefore limit any algal development and lacustrine enrichment.

Mid-late Holocene: from 3050 BC to AD 1910. From 5000 cal. $\mathrm{BP}$ (i.e. $3050 \mathrm{BC}$ ) to $\mathrm{AD} 1910$, the sedimentary organic matter recorded in Lake Majeur is essentially made of pedological markers (Figure 6a) similar to those identified within the watershed (Figure 5b). The lacustrine organic composition thereby indicates that mid-late Holocene organic-rich sediments mostly result from the erosion of soils and peat bogs present throughout the watershed of Lake Majeur. This organic-rich material reflects both the nonconnection of Lake Majeur with glacial supply (Guyard et al., 2007; Leonard, 1986) for at least 5000 years (Figure 4 and Table 1) and the predominance of allochthonous inputs over the Neoglacial period. This terrestrial organic supply further suggests the dominance of runoff processes within the drainage basin of Lake Majeur since $5000 \mathrm{cal}$. BP. This interpretation seems to match that of Scussolini et al. (2011) who documented a humid climate in the eastern Pyrenees after $4300 \mathrm{cal}$. BP. The accumulation rate of EM11B core was five times higher after approximately $2000 \mathrm{cal}$. BP (Figure 4 and Table 1), suggesting more intense soil destabilization during the second half of the mid-late Holocene. Palaeobotanical studies have identified numerous phases of human activity throughout the eastern Pyrenees during the Holocene (Galop, 2006; Galop et al., 2013; Guiter et al., 2005; Scussolini et al., 2011) and most particularly within the Vicdessos valley after approximately $3000 \mathrm{cal}$. BP (Galop, 1998; Galop and Jalut, 1994). Galop and Jalut (1994) and Guiter et al. (2005) particularly demonstrated that pastoral activities were widespread in the region. Galop et al. (2011) documented that grazing activities and humaninduced disturbances reached their maximum during the last 1000 years throughout eastern Pyrenees and notably within the Vicdessos valley. Such activities increase soil destabilization (Noël et al., 2001). It is therefore not possible to exclude any humaninduced perturbations on the environment and the organic detritism in this part of the Pyrenees during this period. The increased accumulation rate identified after 2000 cal. BP could therefore result both from climatic and anthropogenic forcings.

The Mediaeval Climate Anomaly (i.e. AD 900-1300; Figure 7) corresponds to a drier period largely described through Pyrenean 


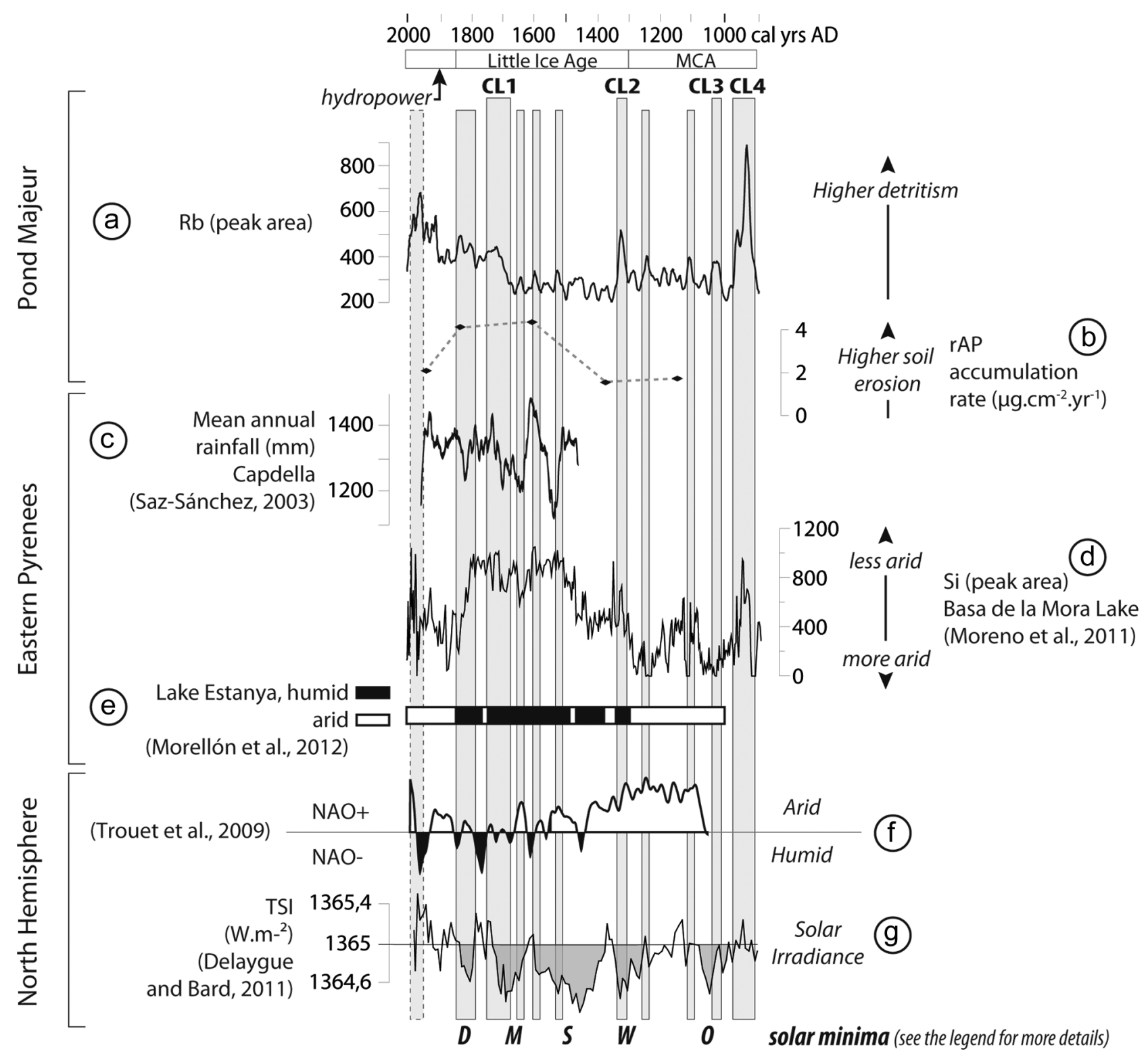

Figure 7. General comparison of the Lake Majeur's minerogenic and organic signals with the lacustrine records from eastern and southern Pyrenees and with climatic records from the Northern Hemisphere. (a) The relative rubidium abundance from core EMIOC is compared with (b) the amount of soil particles transported by runoff processes until Lake Majeur, (c) the mean annual rainfall reconstructed at Capdella by Saz Sánchez (2003), (d) the runoff intensity measured in Lake Basa de la Mora by Moreno et al. (2012), (e) the aridity phases identified in Lake Arreo by Morellón et al. (20I I), (f) the NAO phases reconstructed by Trouet et al. (2009) and (g) the solar irradiance punctuated by solar minima from Delaygue and Bard (20I I). The solar minima are as follows: the Oort minimum (O), the Wolf minimum (W), the Spörer minimum $(S)$, the Maunder minimum (M) and the Dalton one (D).

rAP: red amorphous particles; MCA: Mediaeval Climate Anomaly; NAO: North Atlantic Oscillation.

lacustrine archives (Figure 7d and e, Catalán et al., 2002; Morellón et al., 2011, 2012; Moreno et al., 2012; Scussolini et al., 2011) and European ones (Larocque-Tobler et al., 2010; Luoto and Helama, 2010; Magny et al., 2010) during which climate-induced runoff was reduced (Moreno et al., 2012). Our results suggest that the soil erosion quantified over the Mediaeval Climate Anomaly was essentially resulting from human activities. More specific proxies of anthropogenic pressures, such as pollen data or molecular biomarkers, are, however, needed to clarify our hypothesis in this area of the eastern Pyrenees for this period.

Between $\mathrm{AD} 1400$ and $\mathrm{AD}$ 1600, the amount of soil particles remobilized by runoff is almost twofold (Figure 7b) and matches both the intensive human impacts documented by Galop et al. (2011) in the Vicdessos valley and the wetter climatic conditions documented in the Pyrenees (Figure 7c-e, Morellón et al., 2012; Moreno et al., 2012; Saz Sánchez, 2003). The enhanced soil erosion quantified at Lake Majeur during this period reflects both human impacts and wetter climatic conditions associated with the onset of the 'Little Ice Age' at a regional scale (Moreno et al., 2012).

The minerogenic clastic supply as a marker of hydrological periods during the mid-late Holocene

Drier hydrological periods. After the onset of hydroelectric activities, measurements performed on the EM10A core (i.e. where the accumulation rate was the highest (Figures 4 and $6 \mathrm{~b}$ )) show that the amount of $\mathrm{Rb}$ was particularly important between $\mathrm{AD} 1975 \pm 2$ and $\mathrm{AD} 1982 \pm 2$ (Figures $6 \mathrm{~b}$ and $7 \mathrm{a}$, grey band with hatched contour), suggesting more intense and/or more frequent humaninduced regulations of the lake level, therefore indicating drier climatic conditions. Since Lake Majeur's dams are also used as 
water reservoirs, they can be particularly solicited during drier periods. Romero et al. (1999) have shown that Pyrenean precipitation has witnessed a 30\% reduction between AD 1964 and AD 1993. In addition, this interval corresponds to an abrupt decrease in mean annual rainfall at Capdella (Figures 1 and $7 \mathrm{c}$ ) and arid conditions at Lake Estanya (Figures 1 and 7e), documented by Saz Sánchez (2003) and Morellón et al. (2012), respectively. Interestingly, intense hydro-damming activities during drier and warmer periods are matching positive North Atlantic Oscillation (NAO) phases (Figure 7f; Trouet et al., 2009 and references therein) and higher solar irradiance phases (Figure 7g; Bard et al., 2000; Delaygue and Bard, 2011; Steinhilber et al., 2009). Inversely, lower $\mathrm{Rb}$ content after the start of hydroelectric activities in Lake Majeur lacustrine sediments, such as between AD $1924 \pm 5$ and AD $1975 \pm 2$ (Figure 6b), would reflect periods of limited hydropower activities during more humid periods. Higher $\mathrm{Rb}$ content and sandy particles are found in Lake Sigriou sedimentary infill between $\mathrm{AD} 1925 \pm 20$ and $\mathrm{AD} 1990 \pm 5$ (Figure 4). Because Lake Sigriou is a small and very simple system fed by a small but steep drainage basin covered by grassland and outcropping granites, the deposition of CLs in organic-rich sediments can only be related to enhanced runoff associated with higher precipitation or snowmelt episodes along steep slopes. The presence of CLs therefore confirms a more humid climate during this period and supports our interpretation. This suggests that in spite of the human-induced drastic increase of $\mathrm{Rb}$ content since hydroelectric activities began in Lake Majeur, the minerogenic supply finally reflects climate-controlled fluctuations, since anthropogenic management depends on climatic conditions, in particular, during drier periods.

Wetter hydrological periods. For the mid-late Holocene, agedepth models require improvement by more radiocarbon dating. Nevertheless, the 10 CLs (i.e. CLs composed of sand or gravel) identified in Lake Majeur sedimentary infill have been dated to approximately 4760, 4210, 2640, 1830, 1690, 1380 (AD 570), 1010 (AD 940), 870 (AD 1080), 590 (AD 1360) and 230 cal. BP (AD 1715). The occurrence of these deposits in the entire lacustrine basin and especially below the active canyon confirms that these CLs result from the reactivation of the southern canyon (Figure 2) whose watershed culminates at $1900 \mathrm{~m}$ a.s.l. (hatched line; Figure 1b). Because synchronous detrital events (i.e. coarse layers) were also identified within the organic sedimentation of Lake Sigriou (overhanging Lake Majeur and whose drainage basin also culminates at $1990 \mathrm{~m}$ a.s.1.; Figure 1b), we consider that only climatic forcing could reactivate the two canyons, notably around $\mathrm{AD} 600$, AD 910, AD 1020, AD 1380 and AD 1695. García-Ruiz et al. (1986) demonstrated that $1600 \mathrm{~m}$ a.s.l. represents today the level above which snow accumulates over a long period in the Pyrenees. Such minerogenic deposits could therefore result from intense rainfall or snowmelt events which can affect the upper zones of the drainage basin and transport blocks, gravel and sand into the lake basin. Their reoccurrence is therefore indicative of the chronology of the main hydrological events affecting the Vicdessos valley during the mid-late Holocene.

Before AD 1000, such correlation between mid-late Holocene minerogenic supply and humid climatic phases seems to correspond with wetter and colder time intervals in the Alps (Holzhauser et al., 2005; Joerin et al., 2006) probably linked to negative NAO phases (Björck et al., 2006; Chapron et al., 2002; Guyard et al., 2013; Roberts et al., 2012). The numerous sandy layers dating from approximately $4960 \mathrm{cal}$. BP (CL10 and CL9; Figures 3 and 4) in Lake Majeur reflect abrupt and chronic hydrological changes and could thereby correspond to the onset of the Neoglacial period dated to $c .5000 \mathrm{cal}$. BP in the French Alps (Deline and Orombelli, 2005; Magny et al., 2006; Simonneau et al., in press).
The periods dating from $c .2640 \pm 95,1830 \pm 80$ and $1690 \pm$ $75 \mathrm{cal}$. BP also coincide with wetter phases recorded through the Pyrenees (Morellón et al., 2011; Scussolini et al., 2011), the Jura Mountains and the French Alps (Haas et al., 1998; Magny, 2004, 2010). They, in particular, match two major enhanced flooding periods recorded in Lake Le Bourget by Debret et al. (2010) between 2800-2400 cal. BP and 2100-1100 cal. BP.

During the Mediaeval Climate Anomaly (i.e. AD 900-1300; Figure 7), the minerogenic clastic supply recorded in the EM10C core (i.e. the core the most sensitive to canyon supply and to potential hydrological events) also highlights numerous wetter climatic phases (Figure 7a). The two periods dating from $c$. AD 940 and $\mathrm{AD} 1080$ are recorded through the entire lacustrine basin (CL3 and CL4, Figures 3, 4 and 7a), whereas those from $c$. AD 1100 and $\mathrm{AD} 1250$ are only present in the EM10C core (Figure 7a) and suggest less-intense hydrological events. CL3 and CL4 match CLs in Lake Sigriou (Figures 3 and 4) confirming that the hydrological events were sufficiently intense to be recorded in the two lakes. Within the age-depth model errors, all these periods are synchronous to colder and wetter phases documented both through the eastern Pyrenees (Figures 1 and 7d; Catalán et al., 2002; Corella et al., 2011; Moreno et al., 2012; Pla-Rabes and Catalán, 2011; Scussolini et al., 2011) and the European Alps (Larocque-Tobler et al., 2010; Trachsel et al., 2012). They also match solar minima, such as the Oort and the Wolf ones (Figure 7g; Bard et al., 2000; Delaygue and Bard, 2011; Steinhilber et al., 2009), which coincided with rising lake levels throughout Europe (Beer et al., 2000; Mayewski et al., 1997).

Between $\mathrm{AD} 1300$ and $\mathrm{AD} 1850$, the minerogenic clastic supply recorded in Lake Majeur sediments (Figure 7a) suggests two trends. From AD 1300 to AD 1500, one major hydrological event, dated to $c$. $\mathrm{AD} 1360$, is recorded in the entire lacustrine basin (CL2, Figures 3, 4 and 7). This deposit matches a CL in Lake Sigriou (dated from $\mathrm{AD} 1380 \pm 95$; Figure 4), suggesting that the two canyons were reactivated by climatic deterioration. Besides, this time interval corresponds to wetter climatic conditions documented in the eastern Pyrenees by Saz Sánchez (2003), Moreno et al. (2012) and Morellón et al. (2011) (Figure 7c-e) and the end of the Wolf solar minimum (Figure 7g; Bard et al., 2000; Delaygue and Bard, 2011; Steinhilber et al., 2009). This period also coincides with the onset of the 'Little Ice Age', dated to $c$. AD 1300 in the Pyrenees by Moreno et al. (2012) and Morellón et al. (2011, 2012). After $\mathrm{AD} 1500$, the $\mathrm{Rb}$ peaks, which are correlated to wetter climatic periods, increased in frequency (Figure 7a). It thus seems very likely that these periods, dated $c$. AD 1530, AD 1600, AD 1650, $\mathrm{AD} 1710$ and $\mathrm{AD} 1820$ (Figure 7; grey bands with black contours), correspond to periods of enhanced runoff processes inducing more frequent and more intense weathering of the granite. Some CLs, dated from $\mathrm{AD}$ 1535, AD 1575 and $\mathrm{AD} 1805$ are present in Lake Sigriou sedimentary infill. Lake Sigriou is more sensitive to humid episodes. The synchronicity between the sandy layers recorded in Lake Sigriou and the higher $\mathrm{Rb}$ content observed in Lake Majeur confirms that $\mathrm{Rb}$ fluctuations in Lake Majeur are correlated to hydrological regimes and suggests that Lake Sigriou would be more sensitive than Lake Majeur to minor hydrological events. Higher mean annual rainfall is documented at Capdella after $c$. AD 1600 (Figures 1 and 7c; Saz Sánchez, 2003), and less arid phases are documented in Lakes Basa de la Mora (Figures 1 and 7d; Moreno et al., 2012) and Estanya (Figures 1 and 7e; Morellón et al., 2012) after c. AD 1480. Moreover, the CLs correspond to Western Europe climate deterioration phases (LarocqueTobler et al., 2010; Luterbacher et al., 2001; Magny et al., 2010) enhancing runoff processes over the Pyrenees (Figures $7 \mathrm{~d}$ and e; Corella et al., 2011; Morellón et al., 2011, 2012; Moreno et al., 2012), the Alps (Chapron et al., 2002; Holzhauser and Zumbühl, 1999; Magny et al., 2010) and the Jura Mountains (Magny et al., 2011). This link between the CLs and the climate shows further 
consistency (1) with changes in the NAO index which remains essentially negative (Figure 7f; Trouet et al., 2009), indicating wetter conditions in central Europe (Luterbacher et al., 2001) and in the Pyrenees (Roberts et al., 2012) and (2) with the Spörer and the Maunder solar minima (Figure 7g; Bard et al., 2000; Delaygue and Bard, 2011; Steinhilber et al., 2009) favouring a colder climate. This bipartition of the 'Little Ice Age' suggests that the period AD 1500-1850 was wetter than that of AD 1300-1500.

\section{Conclusion}

Recent climatic and anthropogenic imprints on lacustrine sediments have been documented through the confrontation of organic and mineral markers with historical data. The organic and minerogenic signatures indicate that during the mid-late Holocene, the lacustrine sediment of Lake Majeur resulted from the erosion of the surrounding soils by runoff processes, possibly amplified by human activities after c. $2000 \mathrm{cal}$. BP. The mid-late Holocene was regularly interrupted by CLs affecting both Lake Majeur and Sigriou and reflecting the high sensitivity of the two active canyons to intense rainfall or snowmelt periods and therefore these layers were used to identify hydrological events. The wetter periods have been dated to $c$. AD 1820, AD 1710, AD 1650, $\mathrm{AD} 1600, \mathrm{AD} 1530, \mathrm{AD} 1360, \mathrm{AD} 1080$, AD 940 and $\mathrm{AD} 570$ and recorded in the two systems, confirming that such deposits testify climatic deterioration. During the mid-late Holocene, the CLs, dated from 1690, 1830, 2640, 4210 and 4760 cal. BP, match Alpine climatic deterioration phases. During the past century, results suggest that hydropower production affected $37 \%$ of the lacustrine basin of Lake Majeur, and has induced a fourfold increase of the accumulation rate. Such installation has not only modified the sedimentary dynamic of the lake but also changed its trophic level enhancing algal blooms. The consequence of hydro-damming on water enrichment seems to be specific of activities without pumping but only by artificial lowstand periods. Since AD 1907, the minerogenic supply in Lake Majeur can still be used as a climatic marker since higher contents in $\mathrm{Rb}$ are associated with drier climates when water reservoirs are more solicited, which results in lowstands below former natural lake levels.

\section{Acknowledgements}

This research was integrated and founded by the Observatoire Hommes-Milieux (OHM) du Haut Vicdessos (EMPAL 2010 and ALTOS 2011 projects) (Labex DRIIHM - CNRS INEE). We gratefully thank ISTO members (Disnar Jean-Robert, Boscardin Rachel and Hatton Marielle) and Gratuze Bernard (IRAMAT Orléans) for their valuable advice during analyses. Patrick Bart (CEFREM Perpignan) is also acknowledged for his help during fieldwork campaigns. The Artemis radiocarbon committee (INSU/CNRS) is thanked for radiocarbon dating. Anaëlle Simonneau is a postdoc fellow from the Labex DRHIIM. We would also like to warmly thank Dominique and Philippe Dupui for logistical support and Mario Morellón and Ana Moreno for fruitful scientific exchanges. Two anonymous reviewers improved this manuscript.

\section{Funding}

Anaëlle Simonneau benefited from a $\mathrm{PhD}$ grant provided by the Region Centre.

\section{References}

Anselmetti FS, Bühler R, Finger D et al. (2007) Effects of Alpine hydropower dams on particle transport and lacustrine sedimentation. Aquatic Sciences 69: 179-198.

Appleby PG and Oldfield F (1978) The calculation of lead-210 dates assuming a constant rate of supply of unsupported ${ }^{210} \mathrm{~Pb}$ to the sediment. Catena 5: $1-8$.
Aries S, Motellica-Heino M, Freydier R et al. (2001) Direct determination of lead isotope ratios by laser ablation-inductively coupled plasma-quadrupole mass spectrometry in lake sediment samples. Geostandards Newsletter The Journal of Geostandards and Geoanalysis 25: 387-398.

Ariztegui D, Chondrogianni C, Lami A et al. (2001) Lacustrine organic matter and the Holocene palaeoenvironmental record of Lake Albano (central Italy). Journal of Paleolimnology 26: 283-292.

Baran P, Delacoste M, Dauba F et al. (1995) Effects of reduced flow on brown trout (Salmo trutta L.) populations downstream dams in French Pyrenees. Regulated Rivers: Research \& Management 10(2-4): 347-361.

Bard E, Raisbeck G, Yiou F et al. (2000) Solar irradiance during the last 1200 years based on cosmogenic nuclides. Tellus B 52: 985-992.

Beer J, Mende W and Stellmacher R (2000) The role of the sun in climate forcing. Quaternary Science Reviews 19: 403-415.

Behar F, Beaumont V, De B et al. (2001) Rock-Eval 6 technology: Performances and developments. Oil and Gas Science and Technology 56: 111-134.

Björck S, Rittenour T, Rosén P et al. (2006) A Holocene lacustrine record in the central North Atlantic: Proxies for volcanic activity, short-term NAO mode validity, and long-term precipitations changes. Quaternary Science Reviews 25: 9-32.

Blaauw M (2010) Methods and code for 'classical' age-modelling of radiocarbon sequences. Quaternary Geochronology 5: 512-518.

Buillit N, Lallier-Vergès E, Disnar JR et al. (1997) Climatic changes and anthropogenic effects during the last millennium attested by the petrographical study of organic matter (Annecy, le Petit Lac; France). Bulletin de la Societe Geologique de France 5: 573-583.

Catalán J, Ventura M, Brancelj A et al. (2002) Seasonal ecosystem variability in remote mountain lakes: Implications for detecting climatic signals in sediment records. Journal of Paleolimnology 28: 25-46.

Chapron E, Desmet M, De Putter T et al. (2002) Climatic variability in the northwestern Alps, France, as evidence by 600 years of terrigenous sedimentation in Lake Le Bourget. The Holocene 12: 177-185.

Corella JP, Moreno A, Morellón M et al. (2011) Climate and human impact on a meromictic lake during the last 6,000 years (Montcortès Lake, Central Pyrenees, Spain). Journal of Paleolimnology 46: 351-367.

Croudace IW, Rindby A and Rothwell RG (2006) ITRAX: Description and evaluation of a new multi-function X-ray core scanner. In: Rothwell RG (ed.) New Techniques in Sediment Core Analysis. London: Geological Society Special Publications, pp. 51-63.

Debret M, Chapron E, Desmet M et al. (2010) North western Alps Holocene paleohydrology recorded by flooding activity in Lake Le Bourget, France. Quaternary Science Reviews 29: 2185-2200.

Delaygue G and Bard E (2011) An Antarctic view of Beryllium-10 and solar activity for the past millennium. Climate Dynamics 36: 2201-2218.

Deline P and Orombelli G (2005) Glacier fluctuations in the western Alps during the Neoglacial, as indicated by the Miage morainic amphitheatre (Mont Blanc massif, Italy). Boreas 34: 456-467.

Delmas M, Calvet M, Gunnell Y et al. (2011) Palaeogeography and 10Be exposure-age chronology of the Middle and Late Pleistocene glacier systems in the northern Pyrenees: Implications for reconstructing regional palaeoclimates. Palaeogeography, Palaeoclimatology, Palaeoecology 305: 109-122.

Delsontro T, McGinnis DF, Sobek S et al. (2010) Extreme methane emissions from a Swiss hydropower reservoir: Contribution from bubbling sediments. Environmental Science \& Technology 44: 2419-2425.

Di Giovanni C, Disnar JR, Campy M et al. (1998) Geochemical characterization of soil organic matter and variability of a post glacial detrital organic supply (Chaillexon lake, France). Earth Surface Processes and Landforms 23: $1057-1069$.

Disnar JR, Guillet B, Keravis D et al. (2003) Soil organic matter (SOM) characterization by Rock-Eval pyrolysis: Scope and limitations. Organic Geochemistry 34: 327-343.

Disnar JR, Jacob J, Morched-Issa M et al. (2008) Assessment of peat quality by molecular and bulk geochemical analysis: Application to the Holocene record of the Chautagne marsh (Haute Savoie, France). Chemical Geology 254: 101-112.

Finger D, Bossard P, Schmid M et al. (2007) Effects of Alpine hydropower operations on primary production in a downstream lake. Aquatic Sciences 69: $240-256$

Galop D (1998) La forêt, l'Homme et le troupeau dans les Pyrénées. 6000 ans d'histoire de l'environnement entre Garonne et Méditerranée. Thèse de doctorat, GEODE Laboratoire d'Ecologie Terrestre et FRAMESPA, Toulouse, $303 \mathrm{pp}$.

Galop D (2006) La conquête de la montagne Pyrénéenne au Néolithique. Chronologie, rythmes et transformations des paysages à partir des données polliniques. In: Guilaine J (dir.) Populations néolithiques et environnement. Paris: Editions Errance, pp. 279-295. 
Galop D and Jalut G (1994) Differential human impact and vegetation history in two adjacent Pyrenean valleys in the Ariège basin, southern France, from 3000 B.P. to the present. Vegetation History and Archaeobotany 3: 225-244.

Galop D, Houet T, Mazier F et al. (2011) Grazing activities and biodiversity history in the Pyrenees: New insights on high altitude ecosystems in the framework of a Human-Environment Observatory. PAGES News 19: 53-55.

Galop D, Rius D, Cugny C et al. (2013) Long-term human-environment interactions history in the French Pyrenean Mountains inferred from pollen data. In: Lozny L (ed.) Continuity and Change in Cultural Adaptation to Mountain Environments. Studies in Human Ecology and Adaptation 7. New York: Springer Science + Business Media, pp. 19-30. DOI 10.1007/978-1-4614-5702-2 3.

García-Ruiz JM, Puigdefábregas J and Creus J (1986) La acumulación de la nieve en el Pirineo Central y su influencia Hidrológica [Snow accumulation and its hydrological influence in the Central Spanish Pyrenees]. Pirineos 127: 27-72.

Gratuze B, Blet-Lemarquand M and Barrandon JN (2001) Mass spectrometry with laser sampling: A new tool to characterize archaeological materials. Journal of Radioanalytical and Nuclear Chemistry 247(3): 645-656.

Graz Y, Di Giovanni C, Copard Y et al. (2010) Quantitative palynofacies analysis as a new tool to study transfers of fossil organic matter in recent terrestrial environments. International Journal of Coal Geology 84: 49-62.

Guiter F, Andrieu-Ponel V, Digerfeldt G et al. (2005) Vegetation history and lake-level changes from the Younger Dryas to the present in the Eastern Pyrenees (France): Pollen, plant macrofossils and lithostratigraphy from Lake Racou (2000 m a.s.1.). Vegetation History and Archaeobotany 14: 99-118.

Guyard H, Chapron E, St-Onge G et al. (2007) High-altitude varve records of abrupt environmental changes and mining activity over the last 4000 years in the Western French Alps (Lake Bramant, Grandes Rousses Massif). Quaternary Science Reviews 26: 2644-2660.

Guyard H, Chapron E, St-Onge G et al. (2013) Late-Holocene NAO and oceanic forcing on high-altitude alpine proglacial sedimentation (Lake Bramant, Western French Alps). The Holocene 23: 1163-1172.

Haas JN, Richoz I, Tinner W et al. (1998) Synchronous Holocene climatic oscillations recorded on the Swiss Plateau and at timberline in the Alps. The Holocene 8: 301-309.

Hansen K (1959) The terms Gyttja and Dy. Hydrobiologia 13: 309-315.

Hérail G, Hubschman J and Jalut G (1986) Quaternary glaciation in the French Pyrenees. Quaternary Science Reviews 5: 397-402.

Holzhauser H and Zumbühl HJ (1999) Glacier fluctuations in the western Swiss and French Alps in the 16th century. Climatic Change 43: 223-237.

Holzhauser H, Magny M and Zumbühl HJ (2005) Glacier and lake-level variations in west-central Europe over the last 3500 years. The Holocene 15 789-801.

Jalut G, Aubert S, Galop D et al. (1996) Type regions F-zg and F-r, the northern slope of the Pyrenees. In: Berglund BE, Birks HJB, Ralska-Jasiewiczowa $\mathrm{M}$ and et al. (eds) Palaeoecological Events during the Last 15000 Years - Regional Synthesis of Palaeoecological Studies of Lakes and Mires in Europe. Chichester: John Wiley \& Sons, pp. 612-632.

Jalut G, Michels VT, Dedoubat JJ et al. (2010) Palaeoenvironmental studies in NW Iberia (Cantabrian range): Vegetation history and synthetic approach of the last deglaciation phases in the western Mediterranean. Palaeogeography, Palaeoclimatology, Palaeoecology 297: 330-350.

Jaun M, Finger D, Zeh M et al. (2007) Effects of Alpine hydropower operation and oligotrophication in the light regime of a turbid peri-alpine lake. Aquatic Sciences 69: 212-226.

Joerin UE, Stocker TF and Schlüchter C (2006) Multicentury glacier fluctuations in the Swiss Alps during the Holocene. The Holocene 16: 697-704.

Kunz MJ, Wüest A, Wehrli B et al. (2011) Impact of a large tropical reservoir on riverine transport of sediment, carbon, and nutrients to downstream wetlands. Water Resources Research 47: W12531 (17 pp.).

Lagarrigue T, Baran P, Lascaux JM et al. (2001) Taille à 3 ans de la truite commune (Salmo trutta L.) dans les rivières des Pyrénées françaises: Relations avec les caractéristiques mésologiques et influence des aménagements hydroélectriques. Bulletin Francais de la Peche et de la Pisciculture 357-360: 549-571.

Larocque-Tobler I, Heiri O and Wehrli M (2010) Late Glacial and Holocene temperature changes at Egelsee, Switzerland, reconstructed using subfossil chironomids. Journal of Paleolimnology 43: 649-666.

Lauters F (1992) Impact sur l'écosystème rivière de la gestion par éclusées des ouvrages hydroélectriques: Étude bibliographique. EDF/DER, HE31/92-09.
Leonard EM (1986) Use of lacustrine sedimentary sequences as indicators of Holocene glacial history, Banff National Park, Alberta, Canada. Quaternary Research 26: 218-231.

Le Roux G and Marshall WA (2011) Constructing recent peat accumulation chronologies using atmospheric fall-out radionuclides. Mires and Peat 7: $1-14$.

Luoto TP and Helama S (2010) Palaeoclimatological and palaeolimnological records from fossil midges and tree-rings: The role of the North Atlantic Oscillation in eastern Finland through the Medieval Climate Anomaly and Little Ice Age. Quaternary Science Reviews 29: 2411-2423.

Luterbacher J, Rickli R, Xoplaki E et al. (2001) The Late Maunder Minimum (1675-1715) - A key period for studying decadal scale climatic change in Europe. Climatic Change 49: 441-462.

Magny M (2004) Holocene climate variability as reflected by mid-European lake-level fluctuations and its probable impact on prehistoric human settlements. Quaternary Research 113: 65-79.

Magny M, Arnaud F, Holzhauser H et al. (2010) Solar and proxy-sensitivity imprints on paleohydrological records for the last millennium in westcentral Europe. Quaternary Research 73: 173-179.

Magny M, Leuzinger U, Bortenschlager S et al. (2006) Tripartite climate reversal in Central Europe 5600-5300 years ago. Quaternary Research 65: 3-19.

Magny M, Peyron O, Gauthier E et al. (2011) Quantitative estimates of temperature and precipitation changes over the last millennium from pollen and lake-level data at Lake Joux, Swiss Jura Mountains. Quaternary Research 75: 45-54.

Mayewski PA, Meeker LD, Twickler MS et al. (1997) Major features and forcing of high-latitude northern hemisphere atmospheric circulation using a 110,000- year-long glaciochemical series. Journal of Geophysical Research 102: 26345-26366.

Morellón M, Pérez-Sanz A, Corella JP et al. (2012) A multi-proxy perspective on millennium-long climate variability in the Southern Pyrenees. Climate of the Past 8: 683-700.

Morellón M, Valero-Garcés B, González-Sampériz P et al. (2011) Climate changes and human activities recorded in the sediments of Lake Estanya (NE Spain) during the Medieval Warm Period and Little Ice Age. Journal of Paleolimnology 46: 423-452.

Moreno A, Pérez A, Frigola J et al. (2012) The Medieval Climate Anomaly in the Iberian Peninsula reconstructed from marine and lake records. Quaternary Science Reviews 43: 16-32.

Motellica-Heino M, Rauch S, Morrison GM et al. (2001) Determination of palladium, platinum and rhodium concentrations in urban road sediments by laser ablation-ICP-MS. Analytica Chimica Acta 436: 233244

Mulder T and Cochonat P (1996) Classification of offshore mass movements. Journal of Sedimentary Research 66: 43-57.

Nauman E (1922) Die Bodenablagerungen des Süsswassers. Stuttgart: Archiv für Hydrobiologie.

Noël H, Garbolino E, Brauer A et al. (2001) Human impact and soil erosion during the last $5000 \mathrm{yrs}$ as recorded in lacustrine sedimentary organic matte rat Lac d'Annecy, the French Alps. Journal of Paleolimnology 25: 229-244.

Nomade J, Chapron E, Desmet M et al. (2005) Reconstructing historical seismicity from lake sediments (Lake Laffrey, Western Alps, France). Terra Nova 117(4): 350-357.

Patience AJ, Lallier-Vergès E, Alberic P et al. (1996) Relationship between organo-mineral supply and early diagenesis in the lacustrine environment: A study of superficial sediments from the lac du Bouchet (Haute Loire, France). Quaternary Science Reviews 15: 213-221.

Pla-Rabes S and Catalán J (2011) Deciphering chrysophyte responses to climate seasonality. Journal of Paleolimnology 46: 139-150.

Ramanampisoa L and Disnar JR (1994) Primary control of paleoproduction on organic matter preservation and accumulation in the Kimmeridge Rocks of Yorkshire (UK). Organic Geochemistry 21: 1153-1167.

Reimer PJ, Baillie MGL, Bard E et al. (2009) IntCal09 and Marine09 radiocarbon age calibration curves, $0-50,000$ years cal BP. Radiocarbon $51(4)$ : $1111-1150$.

Reynolds C, Dokulil M and Padisák J (2000) Understanding the assembly of phytoplankton in relation to the trophic spectrum: Where are we now? Hydrobiologia 424: 147-152.

Roberts N, Moreno A, Valero-Garcés BL et al. (2012) Palaeolimnological evidence for an east-west climate see-saw in the Mediterranean since AD900. Global and Planetary Change 84-85: 23-34.

Romero R, Sumner G, Ramis C et al. (1999) A classification of the atmospheric circulation patterns producing significant daily rainfall in the Spanish Mediterranean area. International Journal of Climatology 19: 765-785.

Rosenberg DM, Berkes F, Badaly RA et al. (1997) Large-scale impacts of hydroelectric development. Environmental Reviews 5: 27-54. 
Roussel-Debet S, Renaud P and Métivier JM (2007) 137Cs in French soils: Deposition patterns and 15-year evolution. The Science of the Total Environment 374: $388-398$.

Saz Sánchez MA (2003) Temperaturas y precipitaciones en la mitad norte de España desde el siglo XV. Estudio Dendroclimático (Serie Investigación). Zaragoza: Consejo de Proteccion de la Naturaleza De Aragon.

Scussolini P, Vegas-Vilarrúbia T, Rull V et al. (2011) Middle and Late Holocene climate change and human impact inferred from diatoms, algae and aquatic macrophyte pollen in sediments from Lake Montcortès (NE Iberian Peninsula). Journal of Paleolimnology 46: 369-385.

Sebag D, Copard Y, Di Giovanni C et al. (2006) Palynofacies as useful tool to study origins and transfers of particulate organic matter in recent terrestrial environments: Synopsis and prospects. Earth-Science Reviews 79: 241-259.

Simonneau A, Chapron E, Garçon M et al. (submitted) Tracking Holocene glacial and high altitude alpine environments fluctuations from minerogenic and organic markers in proglacial lacustrine archives (Lake Blanc Huez, Grandes Rousses Massif, Western French Alps).

Simonneau A, Doyen E, Chapron E et al. (2013) Holocene land-use evolution and associated soil erosion in the French Prealps inferred from Lake Paladru sediments and archaeological evidences. Journal of Archaeological Science 40: 1636-1645.
Steinhilber F, Beer J and Fröhlich C (2009) Total solar irradiance during the Holocene. Geophysical Research Letters 36: L19704.

Talbot MR and Livingstone DA (1989) Hydrogen index and carbon isotopes of lacustrine organic matter as lake level indicators. Palaeogeography, Palaeoclimatology, Palaeoecology 70: 121-137.

Trachsel M, Kamenik C, Grosjean M et al. (2012) Multi-archive summer temperature reconstruction for the European Alps, AD 1053-1996. Quaternary Science Reviews 46: 66-79.

Trouet V, Esper J, Graham NE et al. (2009) Persistent positive North Atlantic Oscillation mode dominated the Medieval Climate Anomaly. Science 324: $78-80$

Tyson RV (1995) Sedimentary Organic Matter: Organic Facies and Palynofacies. London: Chapman \& Hall.

Van Rensbergen P, de Batist M, Beck C et al. (1999) High-resolution seismic stratigraphy of glacial to interglacial fill of a deep glacigenic lake: Lake Le Bourget, Northwestern Alps, France. Sedimentary Geology 128: 99-129.

Wirth SB, Girardclos S, Rellstab C et al. (2011) The sedimentary response to a pioneer geo-engineering project: Tracking the Kander River deviation in the sediments of Lake Thun (Switzerland). Sedimentology 58: 1737-1761. 